University of Nebraska - Lincoln

DigitalCommons@University of Nebraska - Lincoln

Faculty Publications from the Harold W. Manter Laboratory of Parasitology

$10-2003$

\title{
Taxonomic Revision of Rhinebothroides (Eucestoda: Tetraphyllidea: Phyllobothriidae), Parasites of Neotropical Freshwater Stingrays (Rajiformes: Myliobatoidei: Potamotrygonidae)
}

Fernando P.L. Marques

Instituto de Biociências

Daniel R. Brooks

University of Toronto,dnlbrooks@gmail.com

Follow this and additional works at: https://digitalcommons.unl.edu/parasitologyfacpubs

Part of the Parasitology Commons

Marques, Fernando P.L. and Brooks, Daniel R., "Taxonomic Revision of Rhinebothroides (Eucestoda: Tetraphyllidea: Phyllobothriidae), Parasites of Neotropical Freshwater Stingrays (Rajiformes: Myliobatoidei: Potamotrygonidae)" (2003). Faculty Publications from the Harold W. Manter Laboratory of Parasitology. 232.

https://digitalcommons.unl.edu/parasitologyfacpubs/232

This Article is brought to you for free and open access by the Parasitology, Harold W. Manter Laboratory of at DigitalCommons@University of Nebraska - Lincoln. It has been accepted for inclusion in Faculty Publications from the Harold W. Manter Laboratory of Parasitology by an authorized administrator of DigitalCommons@University of Nebraska - Lincoln. 


\title{
TAXONOMIC REVISION OF RHINEBOTHROIDES (EUCESTODA: TETRAPHYLLIDEA: PHYLLOBOTHRIIDAE), PARASITES OF NEOTROPICAL FRESHWATER STINGRAYS (RAJIFORMES: MYLIOBATOIDEI: POTAMOTRYGONIDAE)
}

\author{
Fernando P. L. Marques and Daniel R. Brooks* \\ Departamento de Zoologia, Instituto de Biociências, Universidade de São Paulo, Caixa Postal 11461, São Paulo, SP 05422-970, Brazil. e-mail: \\ fernando@ib.usp.br
}

\begin{abstract}
Extensive new collections of specimens of Rhinebothroides spp. from a wide range of Neotropical freshwater potamotrygonid stingrays in numerous localities permitted critical evaluation of the validity of the 7 nominal species in the genus. Some qualitative characters previously used in the taxonomy of this group are highly variable within and among populations, and most morphometric and meristic characters thought to have taxonomic value for this group overlapped among several previously defined nominal species. Characters that were consistent throughout populations and that clearly define morphotypes supported recognition of 4 species: $R$. freitasi (syn. $R$. circularisi and $R$. venezuelensis), $R$. glandularis (syn. $R$. mclennanae), $R$. moralarai, and $R$. scorzai. We provide a taxonomic review of the genus, 8 additional host records, 7 new localities, and an identification key.
\end{abstract}

Species representing 3 genera of phyllobothriid cestodes, Rhinebothroides Mayes, Brooks and Thorson, 1981, Rhinebothrium Linton, 1889, and Anindobothrium Marques, Brooks and Lasso, 2001, have been reported from freshwater potamotrygonids. Of these, only Rhinebothroides spp. occur exclusively in freshwater potamotrygonids (Marques et al., 2001).

The first phyllobothriid cestode described from freshwater potamotrygonids was Rhinebothrium scorzai López-Neyra and Diaz-Ungriá, 1958, in Potamotrygon orbignyi (Castelnau, 1855) from the Orinoco basin. Rego and Dias (1976) described Rhinebothrium paratrygoni in Paratrygon aiereba (Müller and Henle, 1841) from the upper Paraguay drainages. Brooks and Thorson (1976) described Rhinebothrium moralarai in Potamotrygon magdalenae (Valenciennes) from Rio Magdalena, Colombia, in the same year that Rego (1979) described Rhinebothrium freitasi in Potamotrygon orbignyi from Rio Amazonas, Brazil. Mayes et al. (1981) erected Rhinebothroides to receive Rhinebothrium moralarai (as the type species), Rhinebothrium scorzai, and a new species, Rhinebothroides circularisi, inhabiting Potamotrygon constellata (Vaillant) from the upper Amazon, noting that these species differed from species of Rhinebothrium by having ovaries with asymmetrical lobes, bothridia with marginal as well as transverse loculi, and external seminal vesicles inserting near the anterior end of the cirrus sac rather than near the posterior end. Subsequently, Brooks et al. (1981) described Rhinebothroides glandularis and R. venezuelensis inhabiting Potamotrygon orbignyi from the delta of the Orinoco and recognized Rhinebothrium freitasi as a member of Rhinebothroides. The latest species to be placed in this genus was Rhinebothroides mclennanae Brooks and Amato, 1992, inhabiting Potamotrygon motoro (Müller and Henle) from the upper Paraguay region. Currently, Rhinebothroides is represented by 7 nominal species: $R$. circularisi, $R$. freitasi, $R$. glandularis, $R$. mclennanae, $R$. moralarai, $R$. venezuelensis, and $R$. scorzai.

As with many helminth species inhabiting freshwater potamotrygonids, most descriptions of new species have been based on relatively few specimens collected form 1 or a small number of host species in 1 or a few localities. Recent collection of

Received 10 August 2002; accepted 21 April 2003.

* Department of Zoology, University of Toronto, Toronto, Ontario, Canada M5S 3G5. additional specimens from additional hosts and localities, as well as reexamination of previously collected specimens, revealed the need for a taxonomic revision of Rhinebothroides. In this article, we provide such a revision, including new host and distribution records, and a key for the identification of the species of Rhinebothroides that we consider valid.

\section{MATERIALS AND METHODS}

\section{Collection and preparation of specimens}

Specimens of freshwater potamotrygonids were collected using long lines from Rio Paraná (Puerto Reconquista, Santa Fé, Argentina) during February 1995 and from the Amazon region of Brazil during September-December, 1996. Live specimens and the majority of loose proglottides were removed from the spiral valve in situ, placed in freshwater, fixed with hot AFA, and transferred to a cool fixative. After 24 $\mathrm{hr}$, worms were transferred to $70 \%$ ethanol for storage.

Whole mounts of all cestodes were stained with acetocarmine or Mayer's hematoxylin, dehydrated in ethanol, cleared in methyl salycilate, and mounted in Canada balsam. Serial transverse sections of specimens in paraffin were cut at 8- $\mu \mathrm{m}$ intervals and stained with hematoxylin and eosin. Measurements were obtained using an OPITMAS image analysis system attached to a $\mathrm{BH}-2$ Olympus microscope. Measurements include range followed by mean, standard deviation, and sample size. For measurements of sample size equal to 2 only the range is provided in parentheses. All measurements are in micrometers unless otherwise stated. Figures were drawn with the aid of a drawing tube on a $\mathrm{BX}-50$ or $\mathrm{BH}-2$ Olympus microscope. Additional specimens were obtained from the following parasite collections: Coleção Helmintológica do Instituto Oswaldo Cruz, Rio de Janeiro, Brazil (CHIOC); U.S. National Parasite Collection, Biosystematics and National Parasite Collection Unit, USDA, Agricultural Research Service, Beltsville, Maryland (USNPC); and Harold W. Manter Laboratory, University of Nebraska, Lincoln, Nebraska (HWML).

\section{Material examined from museum collections}

Rhinebothroides circularisi, USNPC 76362 (paratype), HWML 21020 (14 paratypes); Rhinebothroides freitasi, CHIOC $31485 \mathrm{~b}-\mathrm{e}$ (paratypes, 3 whole worms and 1 loose proglottides); $R$. venezuelensis, USNPC 75706 ( 2 paratypes), HWML 21005 (8 paratypes), HWML 21006 (13 paratypes), HWML 21024 (5 vouchers), HWML 21025 (3 vouchers), HWML 34092 (vouchers specimens), CHIOC 32818a-f (6 vouchers); $R$. mclennanae, CHIOC 32814a-f (holotype and 5 paratypes); $R$. glandularis, USNPC 75708 (2 paratypes), HWML 21007 (18 paratypes); $R$. moralarai, USNPC 73544 (holotype), USNPC 73545 (2 paratypes), HWML 20255 (3 paratypes); and $R$. scorzai, USNPC 75074 (1 voucher), HWML 21014 (2 vouchers), HWML 21015 (20 vouchers).

\section{Material examined from new collections}

Rhinebothroides freitasi: Eleven mature specimens and 1 postgravid proglottis in Potamotrygon motoro from Puerto Reconquista, Santa Fé, 
Argentina $\left(59^{\circ} 42^{\prime} \mathrm{W}, 29^{\circ} 29^{\prime} \mathrm{S}\right) ; 3$ mature specimens in Potamotrygon falkneri Castex \& Maciel from Rio Apa, Bela Vista, Mato Grosso do Sul, Brazil $\left(56^{\circ} 25^{\prime} \mathrm{W}, 22^{\circ} 4^{\prime} \mathrm{S}\right) ; 3$ incomplete immature and 21 mature complete specimens and 2 detached gravid proglottides in $P$. motoro and 6 complete and 2 incomplete mature specimens, 1 detached mature proglottis, and 1 detached gravid proglottis in $P$. orbignyi from the lower Rio Amazonas, Belém, Pará, Brazil (48 $\left.29^{\prime} \mathrm{W}, 1^{\circ} 27^{\prime} \mathrm{S}\right) ; 6$ mature specimens, 1 detached gravid proglottis, and 2 detached postgravid proglottides in $P$. henlei (Castelnau) from Rio Tocantins, Marabá, Pará, Brazil $\left(49^{\circ} 10^{\prime} \mathrm{W}, 5^{\circ} 23^{\prime} \mathrm{S}\right)$; 1 immature and 6 mature specimens, $1 \mathrm{de}-$ tached gravid proglottis, and 5 detached postgravid proglottides in $P$. motoro from lower Rio Branco, Amazonas, Brazil $\left(61^{\circ} 52^{\prime} \mathrm{W}, 1^{\circ} 19^{\prime} \mathrm{S}\right)$; 2 complete and 1 incomplete immature specimens and 7 mature specimens in P. motoro from Rio Negro, near Barcelos, Amazonas, Brazil $\left(62^{\circ} 58^{\prime} \mathrm{W}, 0^{\circ} 59^{\prime} \mathrm{S}\right) ; 2$ immature and 3 incomplete mature specimens in $P$. schroederi Fernandez-Yepez, 2 immature and 1 incomplete mature specimen and 1 detached mature proglottis in P. scobina Garman, and 3 mature specimens, 9 detached gravid proglottides, and 1 detached postgravid proglottis in P. motoro from lower Rio Solimões, near Manaus, Amazonas, Brazil $\left(60^{\circ} 0^{\prime} \mathrm{W}, 3^{\circ} 6^{\prime} \mathrm{S}\right) ; 2$ mature specimens and 1 detached gravid proglottis in $P$. orbignyi from Orinoco basin, Venezuela $\left(69^{\circ} 20^{\prime} \mathrm{W}, 7^{\circ} 52^{\prime} \mathrm{N}\right)$; and 11 mature specimens in $P$. leopoldi Castex \& Castello, Rio Xingu, Altamira, Pará, Brazil $\left(52^{\circ} 15^{\prime} \mathrm{W}, 3^{\circ} 13^{\prime} \mathrm{S}\right)$.

Rhinebothroides glandularis: Two mature specimens in Potamotrygon motoro from lower Rio Branco, Amazonas, Brazil; 3 immature and 6 mature specimens, 1 detached gravid proglottis, and 2 detached postgravid proglottides in $P$. motoro and 1 mature specimen in $P$. orbignyi from Rio Negro, near Barcelos, Amazonas, Brazil; 19 mature specimens and 3 detached postgravid proglottides in $P$. motoro and 1 mature specimen and 1 detached postgravid proglottis in P. scobina from lower Rio Solimões, near Mamanus, Amazonas, Brazil; 9 mature specimens and 3 detached postgravid proglottides in $P$. henlei from Rio Tocantins, Marabá, Pará, Brazil; 3 immature and 18 mature specimens and 5 detached gravid proglottides in P. motoro and 2 mature specimens and 1 detached postgravid proglottis in P. orbignyi from lower Rio Amazonas, Belém, Pará, Brazil; 9 mature specimens and 3 detached postgravid proglottides in P. motoro from Puerto Reconquista, Santa Fé, Aregentina; 2 mature specimens in $P$. signata Garman from the junction of Rio Poty and Rio Parnaíba, Teresina, Piauí, Brazil $\left(42^{\circ} 46^{\prime} \mathrm{W}, 5^{\circ} 9^{\prime} \mathrm{S}\right)$; and 2 immature specimens in Potamotrygon sp. from Orinoco basin, Venezuela.

Rhinebothoides moralarai: Two immature and 8 mature specimens, 1 detached gravid proglottis, and 7 detached postgravid proglottides in Potamotrygon sp. from Rio Negro, near Barcelos, Amazonas, Brazil.

Rhinebothroides scorzai: Three immature and 3 mature specimens and 5 detached proglottides in Potamotrygon motoro and 4 mature specimens and 1 detached gravid proglottis in Paratrygon aiereba from lower Rio Amazonas, Belém, Pará, Brazil.

All these specimens have been deposited in the Helminthological Collection of the Museum de Zoologia da Universidade de São Paulo, São Paulo, Brazil.

\section{TAXONOMIC ACCOUNTS}

\section{Rhinebothroides Mayes, Brooks and Thorson, 1981}

Diagnosis: Phyllobothriidae. Strobila acraspedote to slightly craspedote. Scolex with 4 sessile or pedicellated bothridia, bearing marginal and transverse loculi, poorly differentiated apical suckers. Genital pores marginal in posterior one-fourth of the proglottis, irregularly alternating. Testes numerous. External seminal vesicle distinct; internal seminal vesicle well developed. Cirrus sac with armed cirrus. Vas deferens joining cirrus sac at anterior margin or in middorsal portion of cirrus sac. Ovary near posterior end of proglottis, $\mathrm{X}$ shaped in cross section; arms asymmetrical. Vagina anterior to cirrus sac; vaginal sphincter present. Vitelline follicles lateral. Uterus saccate, with lateral diverticula. Parasites in spiral valve of freshwater potamotrygonids.
Type species: Rhinebothroides moralarai (Brooks and Thorson, 1976).

\section{Rhinebothroides freitasi (Rego, 1979) Brooks, Mayes, and Thorson, 1981}

(Figs. 1-4)

Syns. Rhinebothrium freitasi Rego, 1979; Rhinebothroides circularisi Mayes, Brooks and Thorson, 1981, new synonym; Rhinebothroides venezuelensis Brooks, Mayes and Thorson, 1981, new synonym

Diagnosis: Bothridia, diamond shaped (Fig. 1A, B). Strobila with 5-25 segments. Testes number, 20-79; posterior preporal testes not reaching vaginal area (Figs. 1D, 2). Cirrus bearing microtriches. Genital atrium inconspicuous, lacking microtriches (Fig. 1C). Insertion of vas deferens at anterior margin of cirrus sac near genital pore (Fig. 1C). Poral ovarian lobe may or may not reach or extend beyond posterior margin of cirrus sac (Fig. 3); aporal lobe may or may not reach posterior aporal testes (Figs. 1D, 2). Vagina varying from semistraight to slightly coiled (Fig. 4). Meristic and morphometric attributes of $R$. freitasi given in Appendix I.

Type host: Potamotrygon orbignyi.

Type locality: Amazon River, Maicuru, Pará, Brazil.

Other hosts: Potamotrygon constellata, P. motoro, P. yepezi Castex and Castello; new host records, P. falkneri, P. henlei, $P$. leopoldi, P. schroederi, and P. scobina.

Distribution: Lago Maracaibo, Rio Orinoco, Rio Amazonas, Rio Solimões, Rio Xingu, Rio Tocantins, and upper Paraguay; new locality records for Rio Negro and Rio Apa (Paraguay River system).

\section{Remarks}

Rego (1979) based his description of $R$. freitasi on 6 complete specimens and on a number of detached proglottides. The type material deposited at the Coleção Helmintológica do Instituto Oswaldo Cruz, however, consisted of 1 complete specimen designated as the holotype (CHIOC 31486a), a vial holding unmounted cestodes (CHIOC 26499), and 4 slides designated as paratypes (CHIOC $31486 \mathrm{~b}-\mathrm{e}$ ). The holotype was not examined in the present study. The vial with unmounted cestodes contained many incomplete specimens of Paraoncomegas sp. (representing a genus of trypanorhynch cestode inhabiting freshwater potamotrygonids), and the paratype series was represented by incomplete specimens and detached proglottides. Thus, the total number of segments $(12-15)$ and the strobilar size $(8.6 \mathrm{~mm})$ reported by Rego (1979) could not be verified, but these values are within the ranges of our specimens (Appendix I). Other values obtained from the paratype series, such as the number of loculi, dimensions of mature and gravid proglottides, testes, cirrus sac, and ovary, as well as the number of testes, overlap with most of the values observed for other populations of what we consider to be $R$. freitasi (Appendix I).

Mayes et al. (1981) distinguished $R$. circularisi from $R$. moralarai and $R$. scorzai but did not discuss Rhinebothrium freitasi (which was described after the manuscript was in press). Brooks et al. (1981) subsequently published a systematic review of cestodes inhabiting freshwater potamotrygonids, in which they assigned Rhinebothrium freitasi to Rhinebothroides, along with a nominal new species, $R$. venezuelensis, inhabiting Po- 

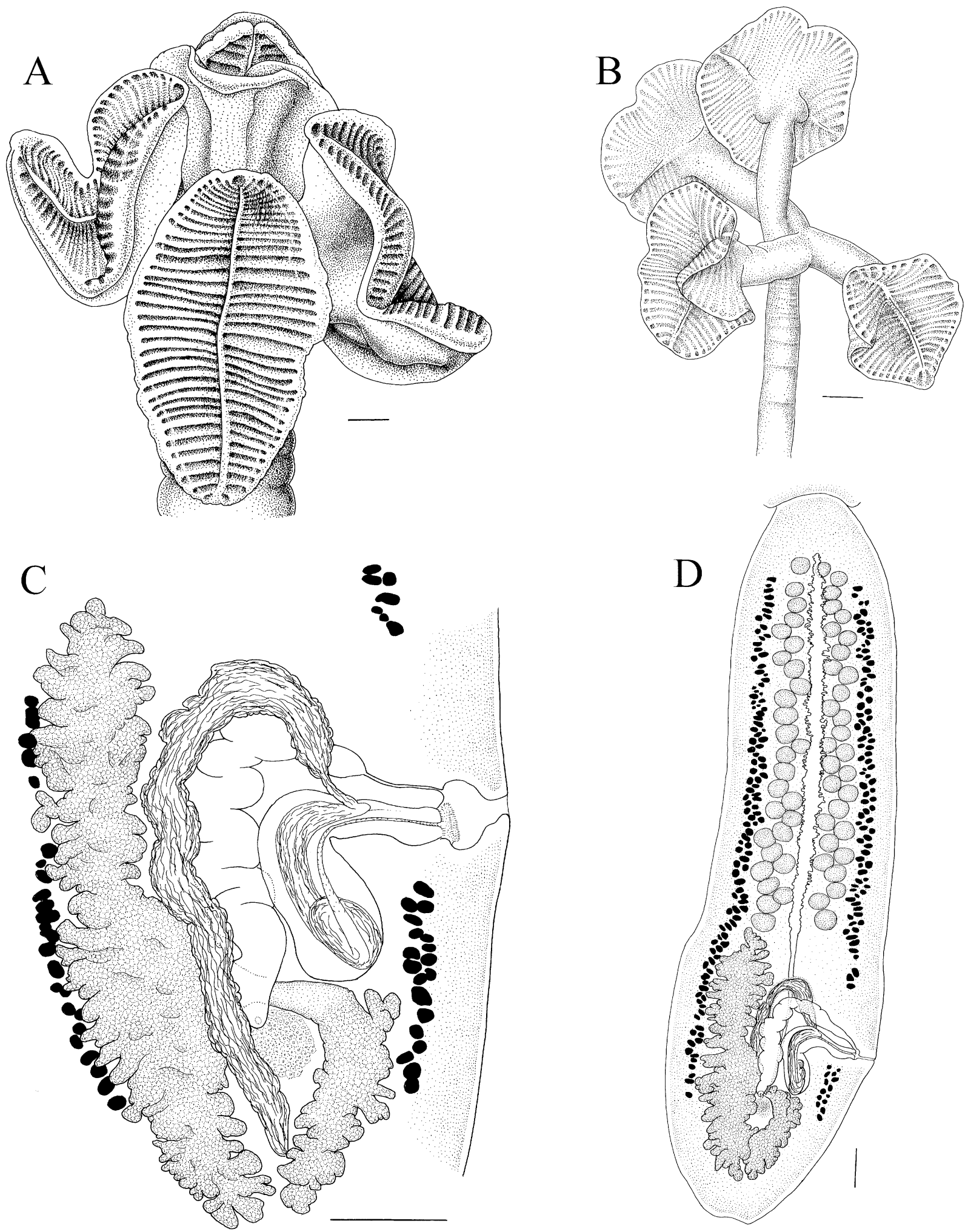

FIGURE 1. Rhinebothroides freitasi. A-B. Scoleces (HWML 21020, paratype of $R$. circularis; CHIOC 31486d, paratype of $R$. freitasi, respec tively). C. Cirrus sac region (HWML 21020). D. Mature terminal proglottis (HWML 21020). Bars $=100 \mu \mathrm{m}$. 

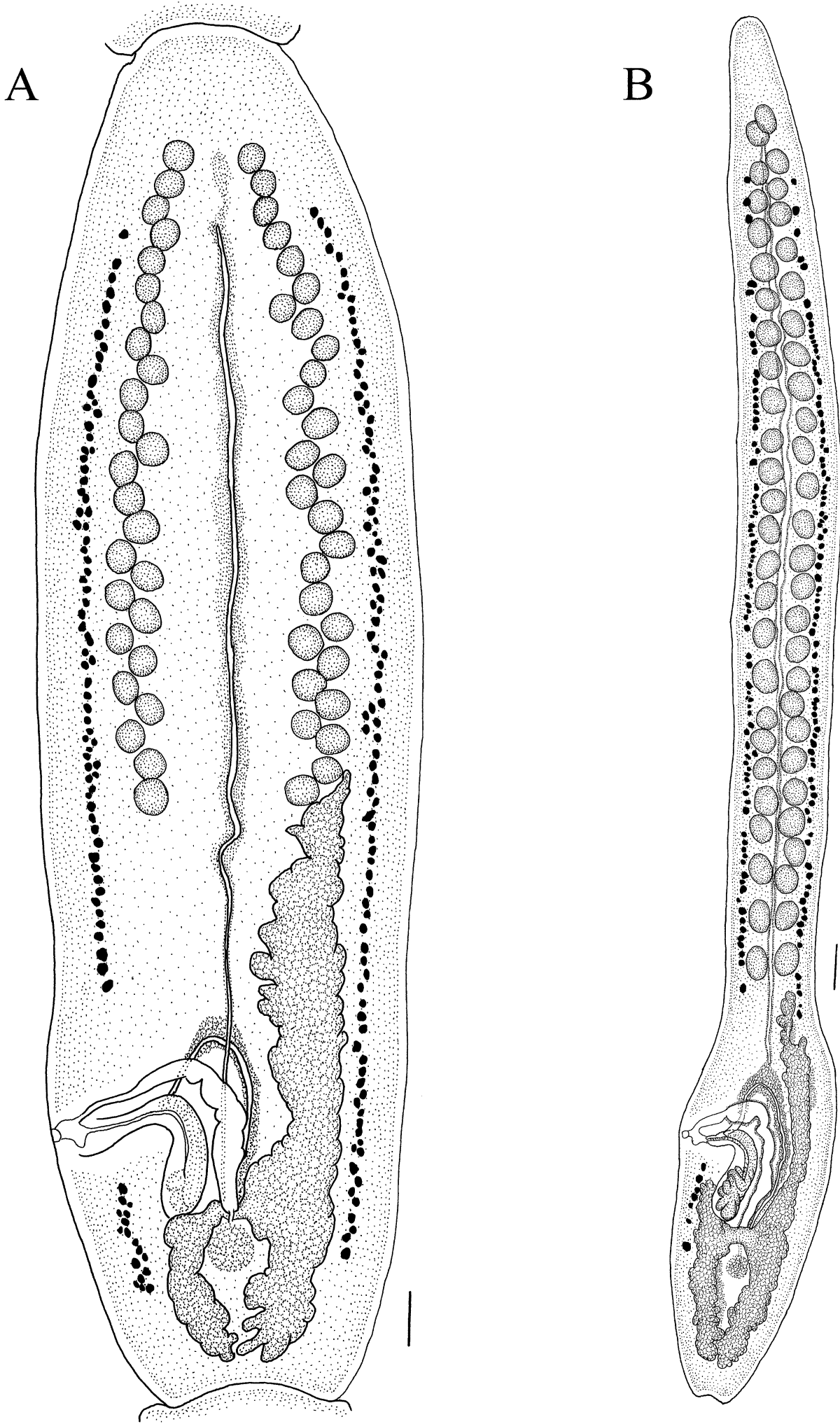

FIGURE 2. Rhinebothroides freitasi. A. Mature proglottis (USNPC 750706, paratype of $R$. venezuelensis). B. Mature detached proglottis (CHIOC $31486 \mathrm{~b}$, paratype of $R$. freitasi). Bars $=100 \mu \mathrm{m}$. 


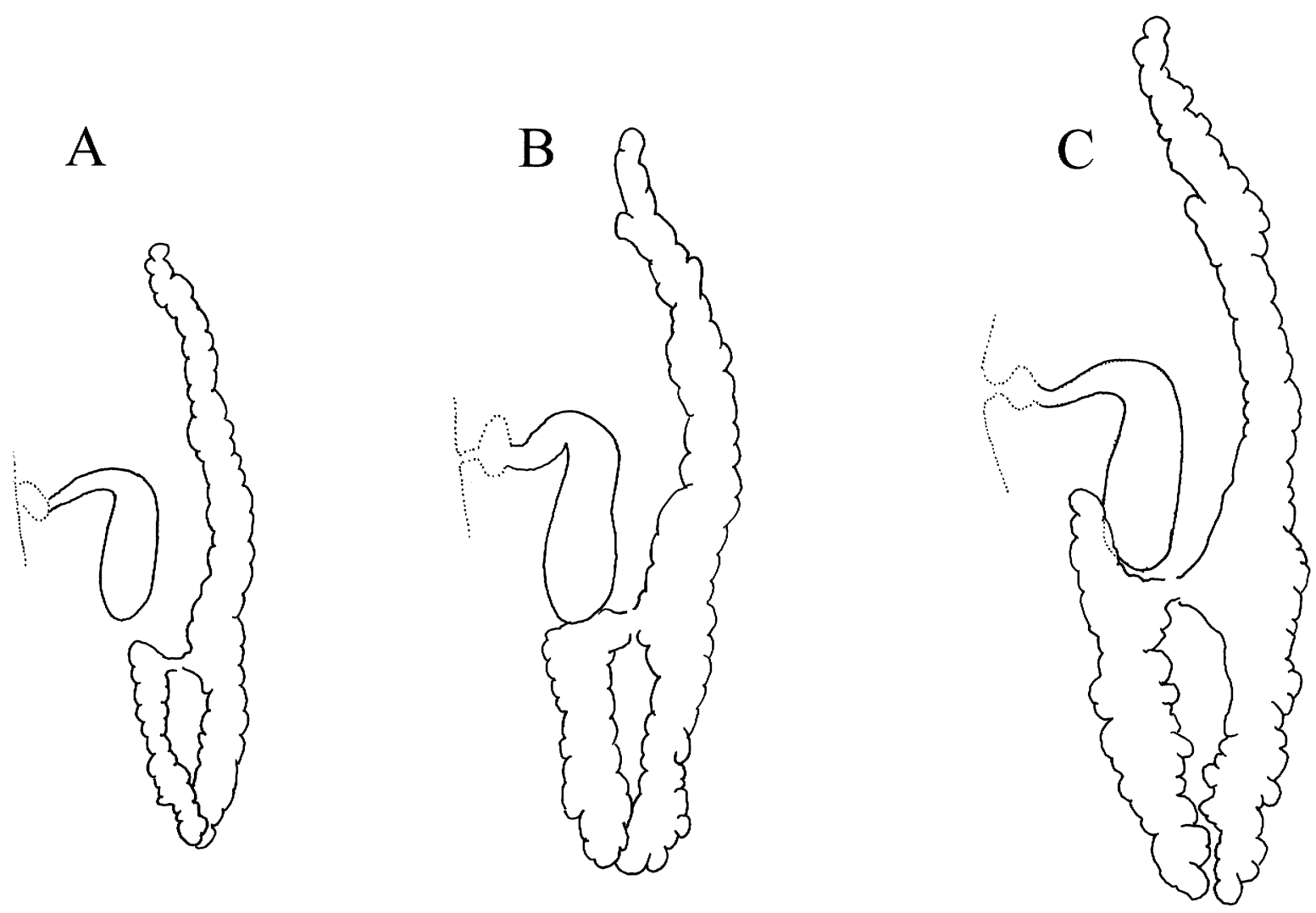

FiguRE 3. Rhinebothroides freitasi. A-C. Variation in length of the ovarian poral lobes in relation to cirrus sac (CHIOC $31486 \mathrm{~b}$, paratype of R. freitasi). Bars $=100 \mu \mathrm{m}$.

tamotrygon orbignyi and $P$. yepezi from Orinoco River and Lago Maracaibo drainages, respectively. They acknowledged that $R$. venezuelensis resembled $R$. circularisi in having a straight vagina, vitelline follicles interrupted near the genital pore, and poral ovarian lobes extending anteriorly only to the posterior margin of the cirrus sac. Nevertheless, they did not discuss the similarities of $R$. venezuelensis with $R$. freitasi. According to Brooks et al. (1981), of the characters shared by $R$. venezuelensis and $R$. circularisi, only the possession of a straight vagina and the distribution of vitelline follicles are found in $R$. freitasi. Rego's (1979) illustration of a detached proglottis (fig. 3 in Rego [1979]) shows the absence of the preovarian vitelline follicles. This feature was used by Brooks et al. (1981) as a diagnostic character for $R$. freitasi. Reexamination of Rego's material and the proglottis illustrated by Rego (1979) (redrawn in Fig. 2B) showed that whereas antiporal vitelline follicles were not observed, vitelline follicles were present postporally. Examination of other proglottides of the type material also reveals their occurrence. In the text, Rego (1979) explicitly described the vitellaria as being "follicular, laterally distributed along the whole length of the proglottis, only interrupted near genital atrium" (Rego, 1979, p. 881, translation by F.P.L.M.).

Reexamination of the type series of $R$. freitasi also revealed that the morphology of the poral ovarian lobe also displays some degree of intraspecific variation (Fig. 3). Rego's (1979) illustration suggests that the poral ovarian lobe extends anteri- orly to the posterior margin of the cirrus sac. This character was also used as diagnostic for this species by Brooks et al. (1981). However, the condition reported for $R$. venezuelensis and $R$. circularisi, in which the poral ovarian lobes extend anteriorly only to the posterior margin of the cirrus sac, is also present in the type series of $R$. freitasi (Fig. 3).

Brooks et al. (1981) distinguished $R$. circularisi from $R$. venezuelensis based on testes number and strobilar morphology. Accordingly, $R$. circularisi was originally described as having a larger number of testes than $R$. venezuelensis (66-88 vs. 4564 , respectively). Reexamination of the specimens used by Mayes et al. (1981) to describe $R$. circularisi indicated that testes number can range from as few as 38 to as many as 79 (Appendix I). As for $R$. venezuelensis, the number of testes ranges from 42 to 61 for the specimens from Orinoco River, 20 to 48 for specimens from Rio Negro, and 35 to 63 for specimens from Lago Maracaibo drainages (Appendix I). Rego (1979) reported 48-64 testes per proglottis for $R$. freitasi. The intraspecific variation found in $R$. circularisi alone suggests that the number of testes is highly variable within populations. The examination of additional specimens also suggests that the number of testes varies greatly among different populations, indicating that the number of testes has little taxonomic value (Appendix I). Other meristic and morphometric attributes, with the exception of the number of loculi for which we have a very small sample size for some populations, were of no use in defining the species considered in this study as synonyms of $R$. 

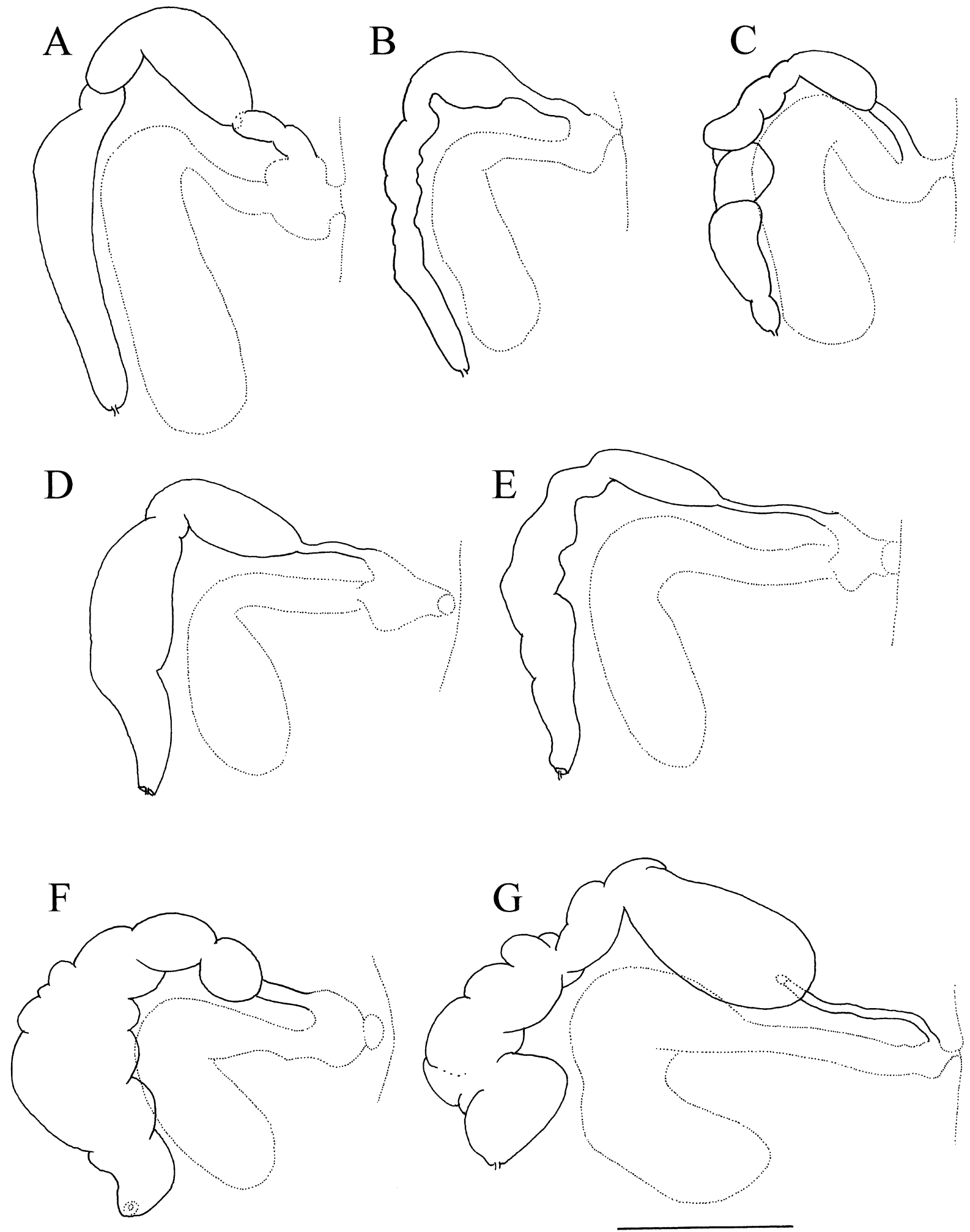

Figure 4. Vaginal morphology in Rhinebothroides freitasi. A-C. Paratype of $R$. freitasi (CHIOC 31486b). D-E. Paratype of $R$. venezuelensis (USNPC 75706). F. Voucher specimen of $R$. circularis (HWML 21020). G. Paratype of $R$. circularisi (USNPC 76362). Bars $=100 \mu m$. 
freitasi because they showed a great degree of overlap among the 12 localities and 9 different host species (Appendix I).

The strobilar condition also proved to be of little value in distinguishing these taxa. Rhinebothroides circularisi was originally described as being acraspedote and $R$. venezuelensis as being craspedote. The paratype series for $R$. freitasi consisted of detached proglottides and immature joined proglottides, which made it difficult to assess the variation within this species. However, examination of specimens attributed to $R$. circularisi and $R$. venezuelensis revealed that there is intraspecific variation of this character within these 2 nominal species. Because the specimens showed varying degrees of relaxation, the assignment of an acraspedote-craspedote condition is difficult in most cases.

As a result of our findings, we propose that Rhinebothroides freitasi be considered the senior synonym of $R$. circularisi and $R$. venezuelensis. Rhinebothroides freitasi (sensu nobis) has previously been reported in Potamotrygon constellata, $P$. orbignyi, $P$. motoro, and P. yepezi (Brooks and Amato, 1992; Brooks, 1995). Rego's (1979) report of Rhinebothroides freitasi inhabiting Potamotrygon histrix (d'Orbigny) in Rio Amazonas is likely erroneous because Potamotrygon histrix is endemic to the Paraná drainage (Rosa, 1985). In this study, we collected $R$. freitasi in 5 additional hosts: Potamotrygon falkneri, $P$. henlei, $P$. leopoldi, $P$. schroederi, and $P$. scobina. Reports of the species were previously restricted to the mid to upper Amazon, the delta of Orinoco River, the Lago Maracaibo tributaries, and the upper Paraguay (Brooks and Amato, 1992; Brooks, 1995). We report $R$. freitasi for the first time from Rio Negro, Rio Xingu, Rio Tocantins, and Rio Apa (Paraguay basin).

\section{Rhinebothroides glandularis Brooks, Mayes and Thorson, 1981 \\ (Figs. 5, 6)}

Syn. Rhinebothroides mclennanae Brooks and Amato, 1992, new synonym

Diagnosis: Bothridia, diamond shaped (Fig. 5A). Strobila with 7-34 segments. Testes number, 17-53; posterior preporal testes not reaching vaginal area (Fig. 5C-D). Cirrus bearing microtriches (Fig. 5B). Genital atrium conspicuous, lined with microtriches. Insertion of vas deferens at the middorsal region of cirrus sac. Poral end of cirrus sac surrounded by darkly staining cells (Fig. 5B). Poral ovarian lobe extending beyond posterior margin of cirrus sac to near midregion; aporal lobe reaching posterior antiporal testes (Fig. 5C). Vagina varying from semistraight to slightly sinuous (Fig. 6). Meristic and morphometric attributes of $R$. glandularis given in Appendix II.

Type host: Potamotrygon orbignyi.

Type locality: Orinoco River delta, near Curiapo, Venezuela.

Other hosts: Potamotrygon motoro, and new host records for Potamotrygon henlei, $P$. scobina, $P$. signata, and Potamotrygon sp. (Venezuela).

Distribution: Rio Orinoco and upper Paraguay; new locality records for lower Rio Amazonas, Rio Solimões, Rio Negro, Rio Tocantins, and Rio Parnaíba.

\section{Remarks}

Brooks et al. (1981) described Rhinebothroides glandularis in Potamotrygon orbignyi from the Orinoco delta in Venezuela.
The most important diagnostic feature of this species was considered to be the presence of "prominent gland cells surrounding the terminal genitalia" (Brooks et al., 1981, p. 57). Brooks and Amato (1992) described Rhinebothroides mclennanae in Potamotrygon motoro from the upper Paraguay, noting that the new species shared the prominent gland cells as well as other characteristics with $R$. glandularis. These authors distinguished $R$. mclennanae from $R$. glandularis by having an average of 31 (with a range of 19-43) testes per proglottis rather than 45 (with a range of 41-51).

Darkly staining glandular cells surrounding the terminal genitalia are not found in any other species of Rhinebothroides nor in any other tetraphyllidean (Brooks and Amato, 1992). Reexamination of the type series of both $R$. glandularis and $R$. mclennanae revealed 2 other morphological features not reported before in members of this genus. Specimens having glandular cells surrounding the terminal genitalia also possess a genital atrium covered with prominent microtriches (Fig. 5B), whereas other Rhinebothroides species lack such microtriches (Fig. 1C) or have only few, and the vas deferens is inserted into the cirrus sac at the middle of the cirrus sac (Fig. 5B) rather than at the anterior margin of the cirrus sac near to the genital pore (Fig. 1C), as in other members of the genus. Our study also revealed that the number of testes varies greatly among and within populations (Appendix II; Fig. 7). Because of this variability, we do not regard the diagnostic features that were used to differentiate $R$. mclennanae from $R$. glandularis as valid. In addition, we were not able to recognize any meristic character (Appendix II) or morphological feature that would allow us to distinguish these 2 nominal species. Consequently, we consider $R$. mclennanae to be a junior synonym of $R$. glandularis.

Rhinebothroides glandularis (sensu nobis) has been previously reported only in Potamotrygon orbignyi and $P$. motoro (Brooks and Amato, 1992; Brooks, 1995). In this study, we report 4 new hosts: Potamotrygon henlei, P. scobina, P. signata, and Potamotrygon sp. (Venezuela). Rhinebothroides glandularis has previously been reported from the delta of the Orinoco and the upper Paraguay (Brooks and Amato, 1992; Brooks, 1995). We report 6 new localities: Rio Branco, Rio Negro, Rio Solimões, Rio Tocantins, lower Rio Amazonas, and Rio Parnaíba.

\section{Rhinebothroides moralarai (Brooks and Thorson, 1976) Brooks, Mayes, and Thorson, 1981}

(Figs. 8-10)

Syn. Rhinebothrium moralarai Brooks and Thorson, 1976

Diagnosis: Bothridia, quadrate. Strobila with 14-45 segments (Fig. 8A-C). Testes number, 43-69; posterior preporal testes not reaching the vaginal area (Fig. 9). Cirrus bearing spines. Genital atrium conspicuous, partially lined with microtriches. Insertion of vas deferens at anterior margin of cirrus sac near genital pore (Fig. 8D). Poral ovarian lobe not extending beyond posterior margin of cirrus sac; aporal lobe extending from posterior antiporal testes to midproglottis (Fig. 9). Vagina semistraight, somewhat saccate, slightly sinuous (Fig. 10). Meristic and morphometric attributes of $R$. moralarai given in Appendix III.

Type host: Potamotrygon magdalenae. 

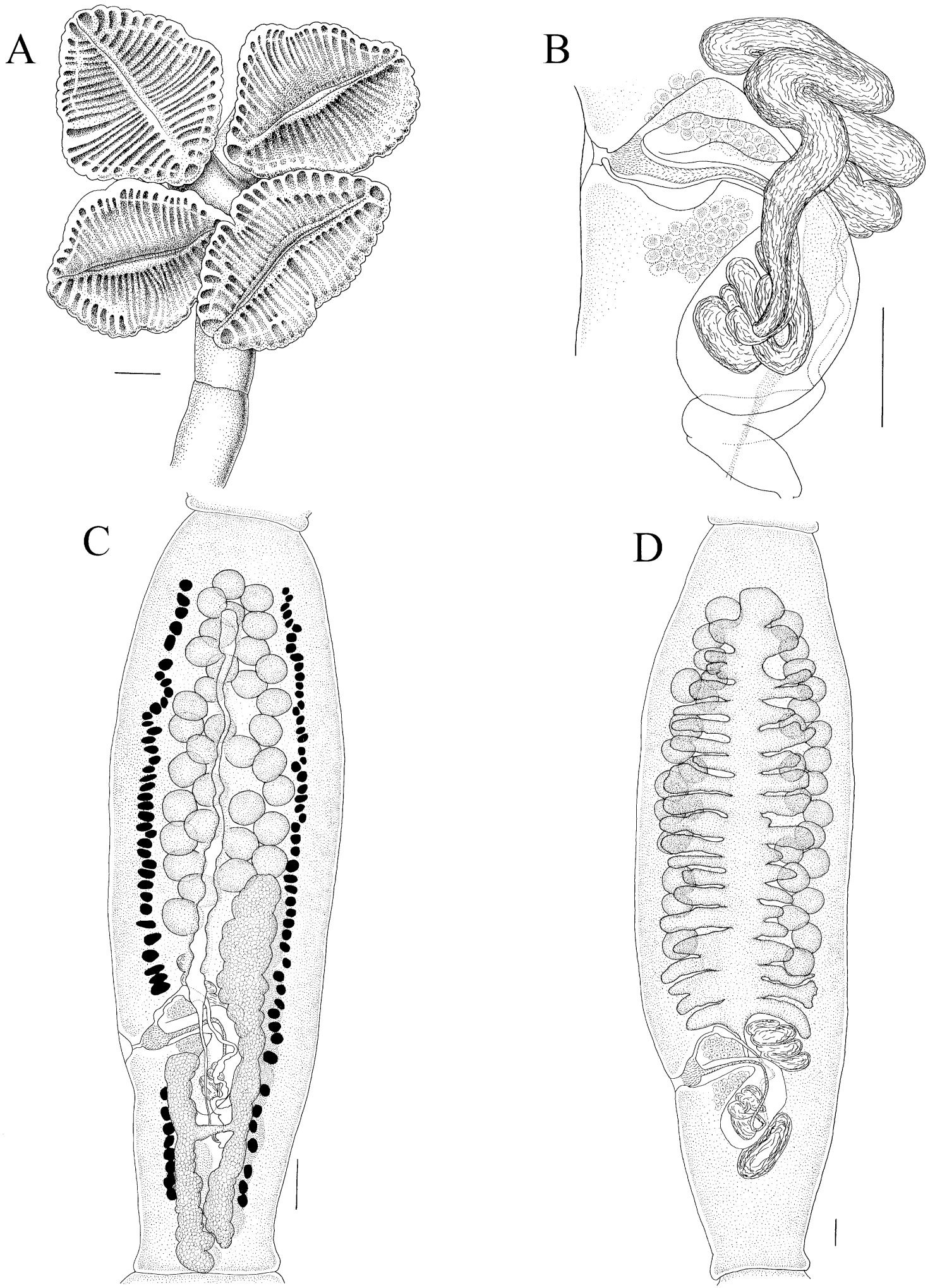

FiguRE 5. Rhinebothroides glandularis. A. Scolex (HWML 21007). B. Cirrus sac region. C. Mature proglottis (HWML 21007). D. Postgravid proglottis (HWML 21007). Bars $=100 \mu \mathrm{m}$. 

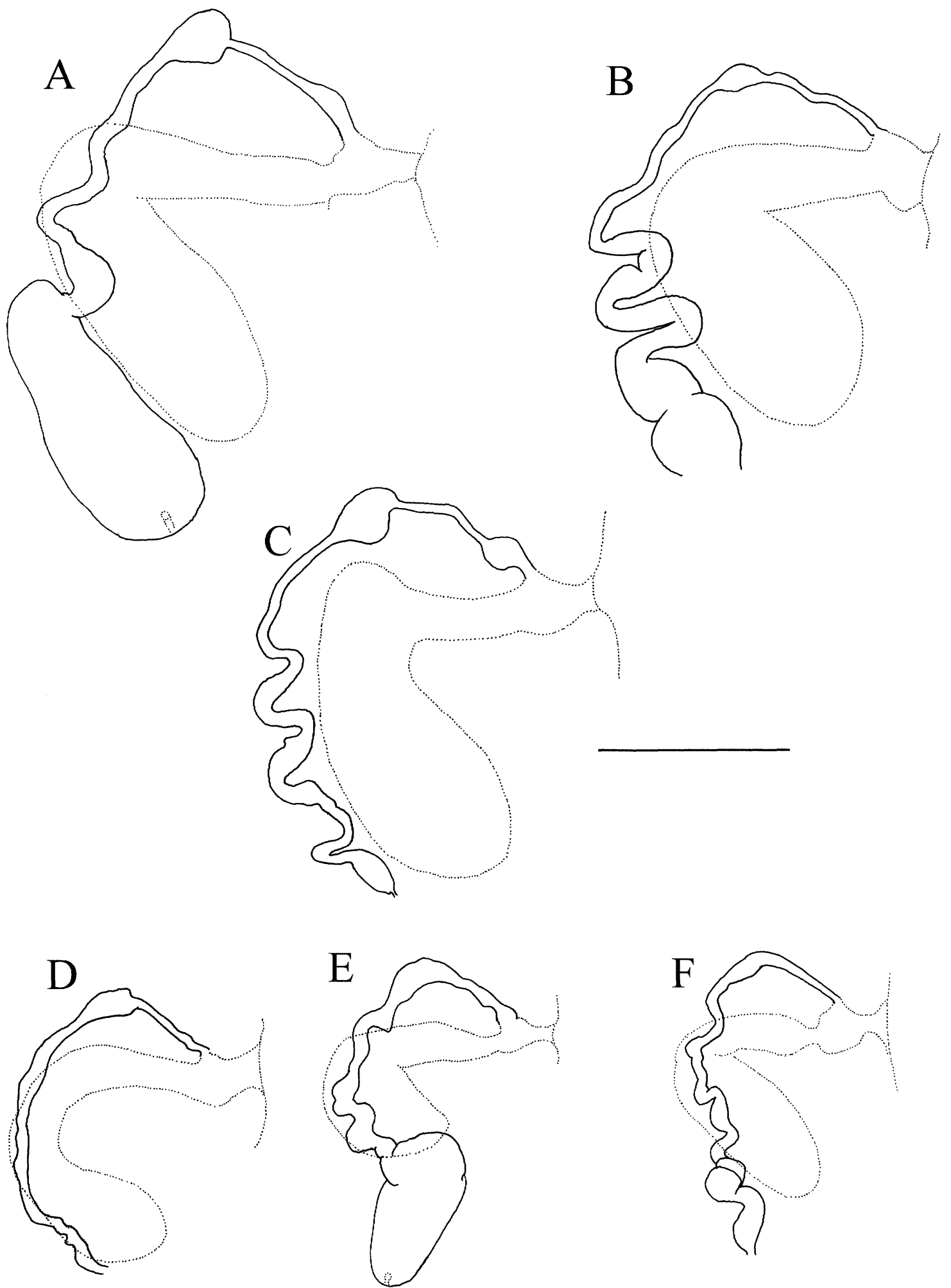

Figure 6. Vaginal morphology. A. R. glandularis (HWML 21007). B-C. R. glandularis (USNPC 75708). D. $R$. mclennanae (CHIOC $32814 \mathrm{e}$, paratype). E. $R$. mclennanae (CHIOC 32814a, holotype). F. $R$. mclennanae (CHIOC 32814c, paratype). Bar $=100 \mu \mathrm{m}$. 


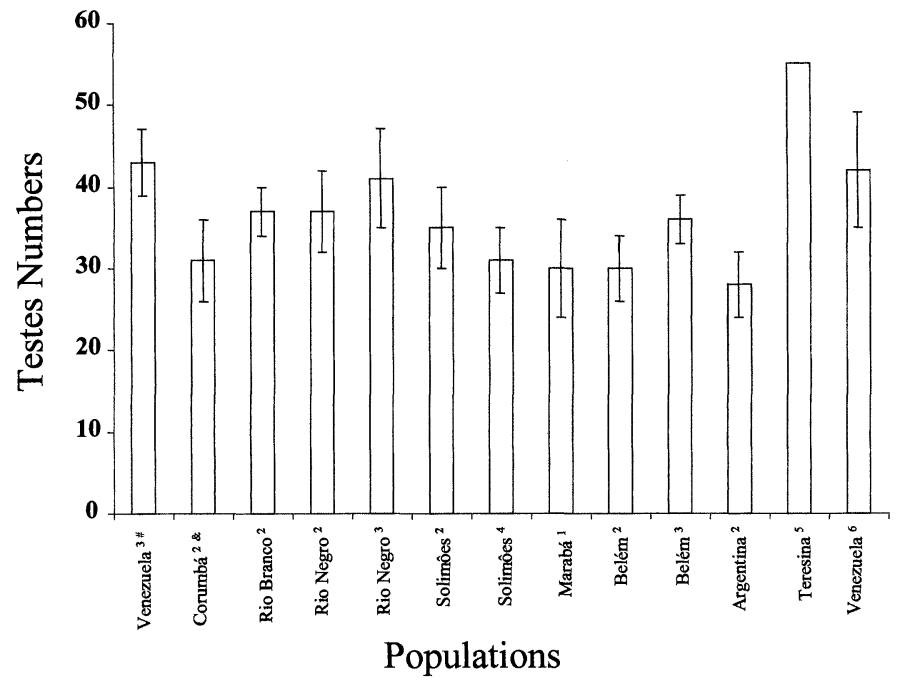

FIGURE 7. Testes average and standard deviation for 13 populations of $R$. glandularis according to geographic area and host. 1. Potamotrygon henlei. 2. $P$. motoro. 3. P. orbignyi. 4. P. scobina. 5. P. signata. 6. Potamotrygon sp. from Venezuela. \# Indicates specimens collected by Brooks and Amato (1992), and \& indicates specimens collected by Brooks et al. (1981b).

Type locality: Magdalena River, Cienaga Rabón, near San Cristóbal, Colombia.

New host: Potamotrygon sp. (upper Rio Negro).

Distribution: Rio Magdalena and upper Rio Negro, new locality.

\section{Remarks}

Brooks and Thorson (1976) described this species as $R h i-$ nebothrium moralarai in Potamotrygon magdalenae, an endemic species of freshwater potamotrygonid from Rio Magdalena, Colombia. Rhinebothroides moralarai possesses 2 diagnostic features that distinguish this species from the others included in the genus: quadrate rather than diamond-shaped bothridia and a heavily, rather than lightly, spined cirrus (Fig. 8D). The distinction between the 2 forms of spination can easily be observed using light microscopy. The specimens from upper Rio Negro do not show any considerable meristic or morphometric differences from those of Rio Magdalena (Appendix III). Also, meristic and morphometric attributes found in $R$. moralarai (Appendix III) are within the ranges observed for $R$. freitasi (Appendix I) and $R$. glandularis (Appendix II).

Rhinebothroides moralarai was previously known to inhabit Potamotrygon magdalenae and, as such, to be endemic to Rio Magdalena. This report of $R$. moralarai in Potamotrygon sp. from the upper Rio Negro constitutes new host and locality records.

\section{Rhinebothroides scorzai (López-Neyra and Diaz-Ungriá, 1958) Brooks, Mayes, and Thorson, 1981} (Figs. 11, 12)

Syn. Rhinebothrium scorzai López-Neyra and Diaz-Ungriá, 1958

Diagnosis: Bothridia, diamond shaped, wider than longer, bearing 63-127 marginal loculi (Fig. 11A). Strobila with 33-
86 segments slightly craspedote (Fig. 11C, D). Testes number, 59-98; posterior preporal testes reaching the vaginal area (Fig. 11C, D). Cirrus bearing microtriches (Fig. 11B). Genital atrium conspicuous, partially covered with microtriches (Fig. 11B, C). Insertion of the vas deferens at the anterior margin of the cirrus sac near to genital pore (Fig. 11B). Poral ovarian lobe extending beyond posterior margin of cirrus sac to level of genital pore; aporal lobe overlapping several posterior aporal testes (Fig. $11 \mathrm{C}, \mathrm{D})$. Vagina straight at the anterior margin of cirrus sac coiling as it descends posteriorly (Fig. 12). Meristic and morphometric attributes of $R$. glandularis are given in Appendix IV.

Type host: Potamotrygon orbignyi.

Type locality: Orinoco River, Venezuela.

Other hosts: Paratrygon aiereba and Potamotrygon motoro, new host.

Distribution: Rio Orinoco, Upper Paraguay (?) (Rego and Dias, 1976, see below), and lower Rio Amazonas, new locality.

\section{Remarks}

Rhinebothroides scorzai was first described as Rhinebothrium scorzai inhabiting Potamotrygon orbignyi (reported as $P$. histrix) from the delta of Orinoco (López-Neyra and Diaz-Ungriá, 1958). Mayes et al. (1981) transferred this species to Rhinebothroides. This species can be distinguished meristically from all other species of Rhinebothroides by having greater number of segments (43-70 in average among populations vs. 7-16 for $R$. freitasi, 13-30 for $R$. glandularis, and 20-36 for $R$. moralarai) and greater number of testes per proglottis (7580 in average among populations vs. 34-62 for $R$. freitasi, 2843 for $R$. glandularis, and 55-59 for $R$. moralarai) (Appendices I-IV). Morphologically, $R$. scorzai can be distinguished from all other species by possessing vitellarian follicles that overlap with the vagina rather than being interrupted before reaching the vaginal area, and poral and aporal testes clustered in somewhat 3 columns rather than in 1 or 2 columns (Fig. 11B, C).

We were unable to examine the type material used in the original description by López-Neyra and Diaz-Ungriá (1958). López-Neyra and Diaz-Ungriá (1958, p. 10) described $R$. scor$z a i$ as being $30 \mathrm{~mm}$ long with 78 proglottides, mature proglottis $1,200-2,000$ long by $1,150-1,320$ wide, and $86-98$ testes. Based on the original description, none of these meristic and morphometric attributes, which were examined in 3 populations inhabiting 3 distinct hosts, deviate from those described originally (Appendix IV). Moreover, our data show that the specimens studied form a concise meristic and morphometric group (Appendix IV).

Rhinebothroides scorzai has been reported in Paratrygon aiereba, Potamotrygon orbignyi, and P. motoro (Brooks and Amato, 1992; Brooks, 1995). In this study, no additional host was reported for this species of Rhinebothroides.

The biogeographical distribution of $R$. scorzai may also be limited. Rhinebothroides scorzai has previously been reported from the upper Paraguay and the delta of the Orinoco River (Brooks and Amato, 1992; Brooks, 1995). The only new locality record reported in this study is the lower Rio Amazonas, in Potamotrygon motoro and P. orbignyi. Rego and Dias (1976) reported $R$. scorzai in Potamotrygon motoro and Paratrygon aiereba from the upper Paraguay system, in the vicinity of Sa- 

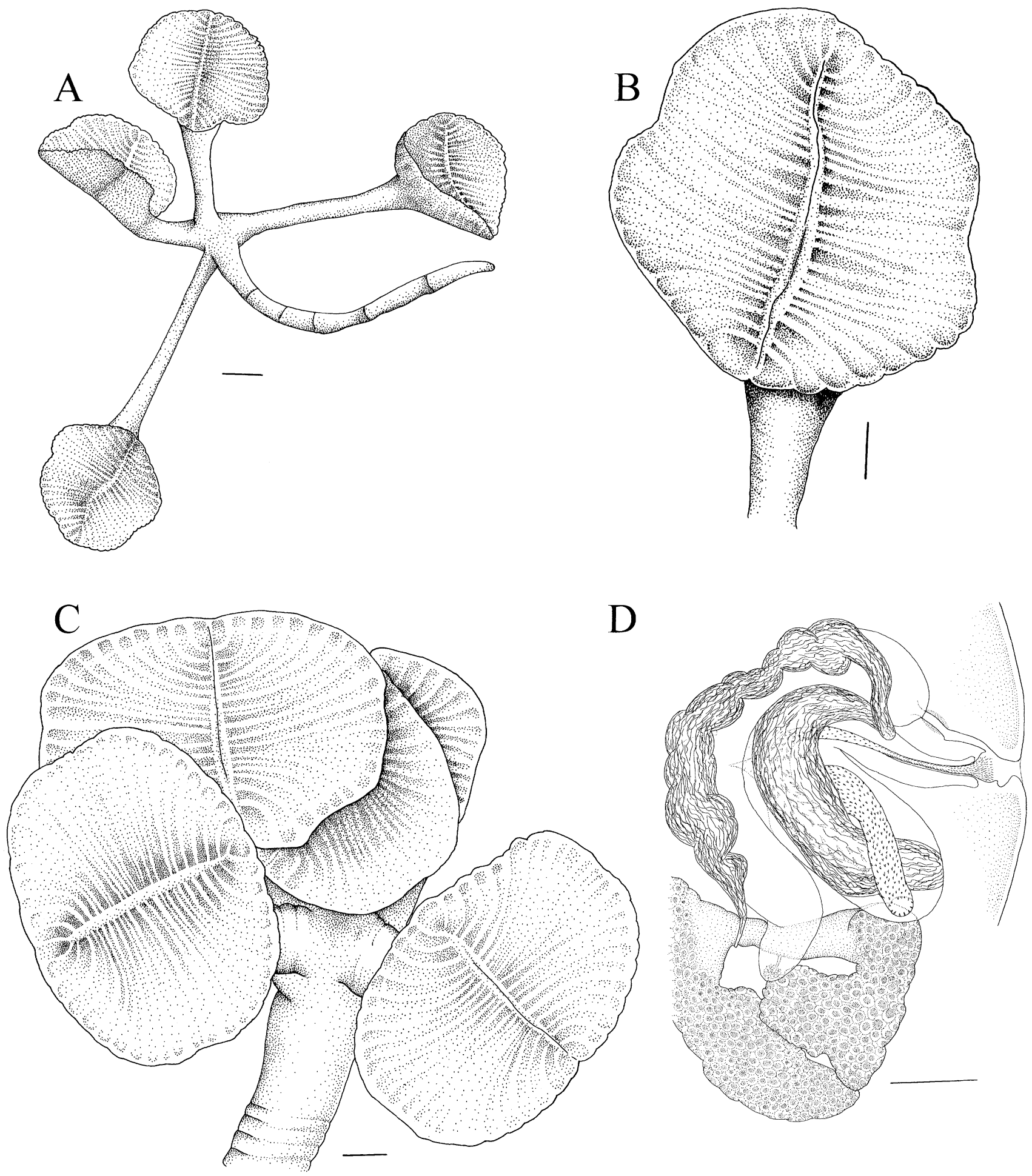

FIGURE 8. Rhinebothroides moralarai. A. Immature specimen (USNPC 73545). B. Detail of bothrium-immature specimen (USNPC 73545). C. Scolex of mature specimens. D. Cirrus sac region. Bars $=100 \mu \mathrm{m}$.

lobra, Mato Grosso do Sul, Brazil. However, their illustrations of proglottides of $R$. scorzai (figs. 4, 5 in Rego and Dias [1976]) are not in agreement with the general morphology of that species. In $R$. scorzai, the poral and aporal testes are arranged approximately in 3 columns, the poral testes reach the vaginal region, the poral ovarian lobe advances beyond the posterior margin of the cirrus sac, the aporal ovarian lobe overlaps the aporal testes, and the vitelline follicles overlap the vagina. In the proglottis illustrated by Rego and Dias (1976), the testes are arranged in a single column anteriorly, which is divided into 2 columns posteriorly, the poral testes do not reach the vaginal region, the poral ovarian lobe reaches only to the level 

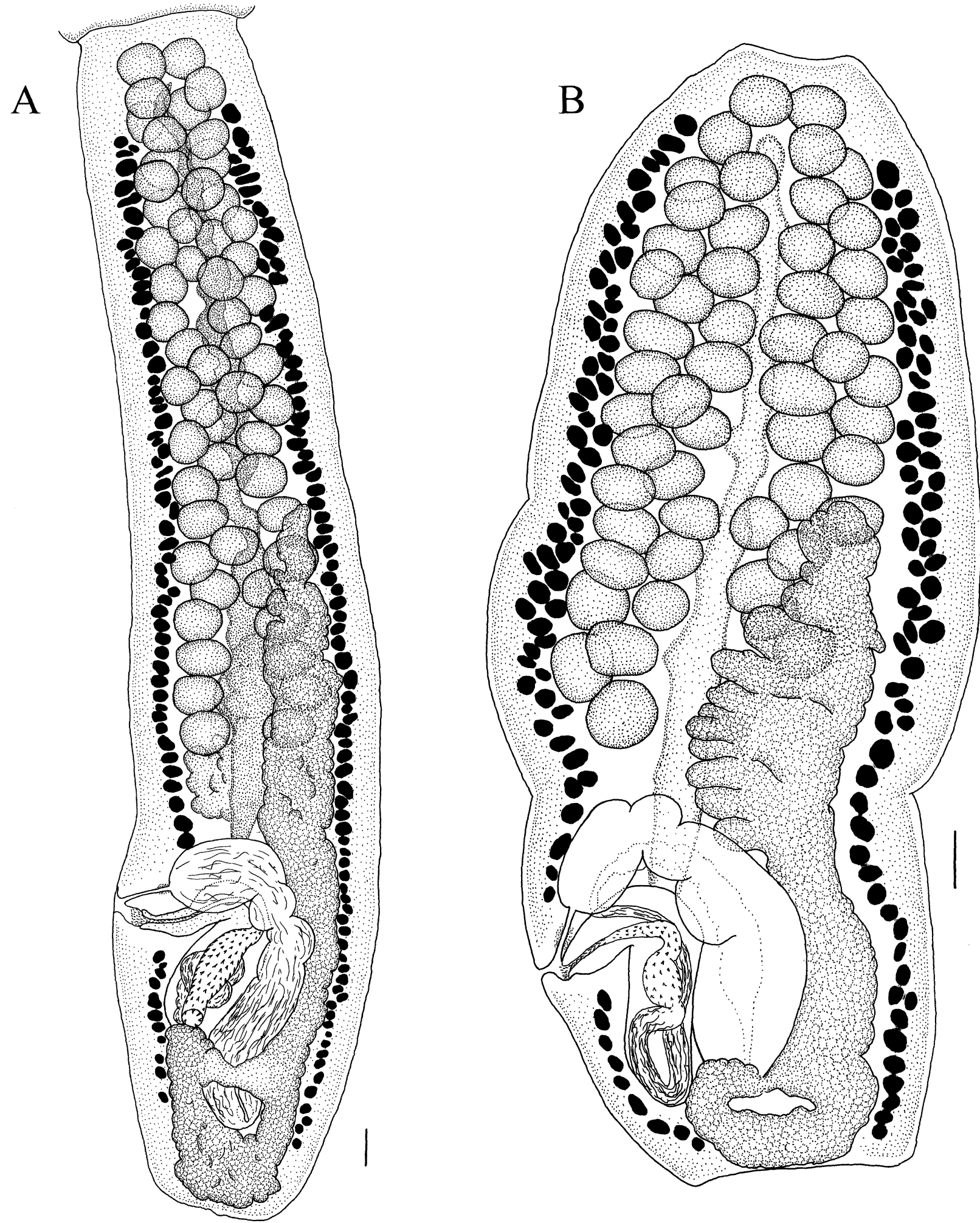

FIGURE 9. Rhinebothroides moralarai. A. Mature proglottis (specimen from Rio Negro). B. Mature proglottis from holotype (USNPC 73544). Bars $=100 \mu \mathrm{m}$. 

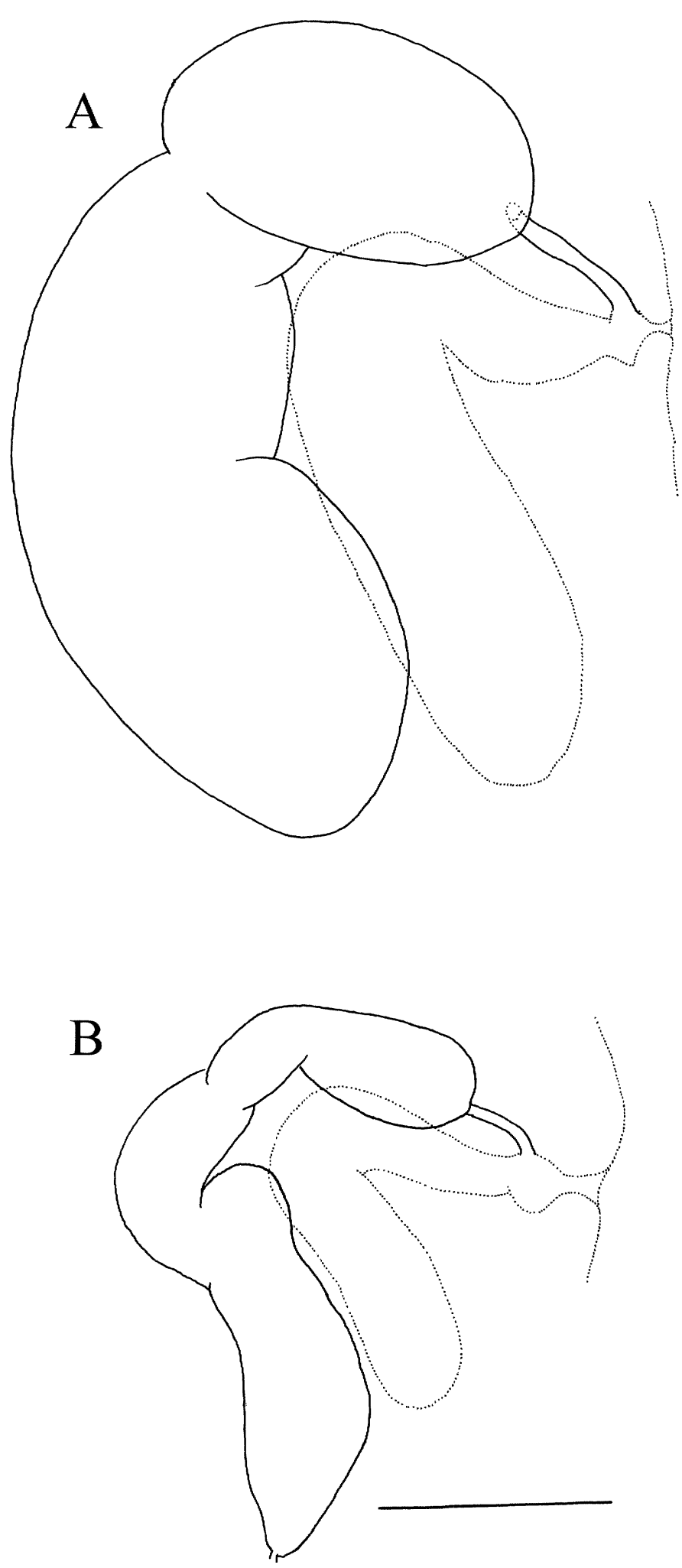

FIGURE 10. Variation in vaginal morphology of Rhinebothroides moralarai. A. Holotype (USNPC 73544). B. Paratype (HWML 20255). Bars $=100 \mu \mathrm{m}$. of the posterior margin of the cirrus sac, the aporal ovarian lobes do not extend anteriorly to the aporal testes, and the vitelline follicles do not overlap the vagina. In these characters, their illustrations more closely resemble $R$. freitasi than $R$. scor$z a i$. The number of testes reported by Rego and Dias (1976) (80-85) are in agreement with the number reported for $R$. scorzai (Appendix IV) but reach the upper limit of the number of testes reported for $R$. freitasi (Appendix I). We were unable to examine the specimens of $R$. scorzai reported by Rego and Dias (1979). Reexamination of these specimens might reveal that their record for R. scorzai inhabiting Potamotrygon motoro and Paratrygon aiereba from upper Paraguay is erroneous. If this is so, $R$. scorzai is restricted to the Orinoco and Amazon basins, and a different species may be present in the upper Paraguay.

\section{Key to the species of Rhinebothroides}

1a. Poral end of cirrus sac surrounded by darkly staining glandular cells, whole atrium bearing microtriches, vas deferens inserted at the midportion of cirrus sac $\ldots \ldots \ldots \ldots$. glandularis

1b. Darkly staining glandular cells surrounding poral end of cirrus sac not present, atrium bearing at most only a few microtriches, vas deferens inserted at the anterior portion of cirrus sac

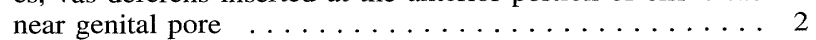

2a. Bothridia quadrate, cirrus bearing spines $\ldots \ldots \ldots$ moralarai

2b. Bothridia diamond shape, cirrus bearing microtriches .... 3

3a. Strobila with 5-25 segments, testes forming single or double columns, genital atrium not lined with microtriches, vitellaria not reaching vaginal area ............... freitasi

3b. Strobila with 35-86 segments, testes forming triple columns, genital atrium partially covered by microtriches . . . R. scorzai

\section{DISCUSSION}

Brooks et al. (1981) provided the only other systematic account of Rhinebothroides, recognizing 6 nominal species. The seventh nominal species was added by Brooks and Amato (1992). However, species of Rhinebothroides have been recognized and described from as few as a single specimen, e.g., Rhinebothrium scorzai by López-Neyra and Diaz-Ungriá (1958), to as many as 70 specimens, e.g., Rhinebothroides mclennanae by Brooks and Amato (1992), and collected in most cases from a single locality and from a single species of host. As would be expected from the limitations resulting from these collections, the morphological and meristic variability within and among populations of Rhinebothroides spp. were poorly understood.

The taxonomy of Rhinebothroides spp. has been based mainly on the number of bothridial loculi, number of testes, distribution of vitelline follicles, morphological attributes of the vagina (coiled vs. straight), ovary (extension of poral lobe in relation to cirrus sac), and strobila (craspedote vs. acraspedote). Because of the wider sampling of hosts and localities encompassed by this study, information on intra- and interspecific variation surfaced, and a critical evaluation of the validity of the nominal species led to a new interpretation of the characters traditionally used in the taxonomy of this group. We found that these characters are highly variable within and among populations of any given species of Rhinebothroides. Most morphometric and meristic characters overlap among previously defined nominal species (Appendices I-IV). This led us to seek characters that were consistent throughout populations and that could clearly define morphotypes and, in turn, define what we considered to be valid species. As a result, we recognize only 

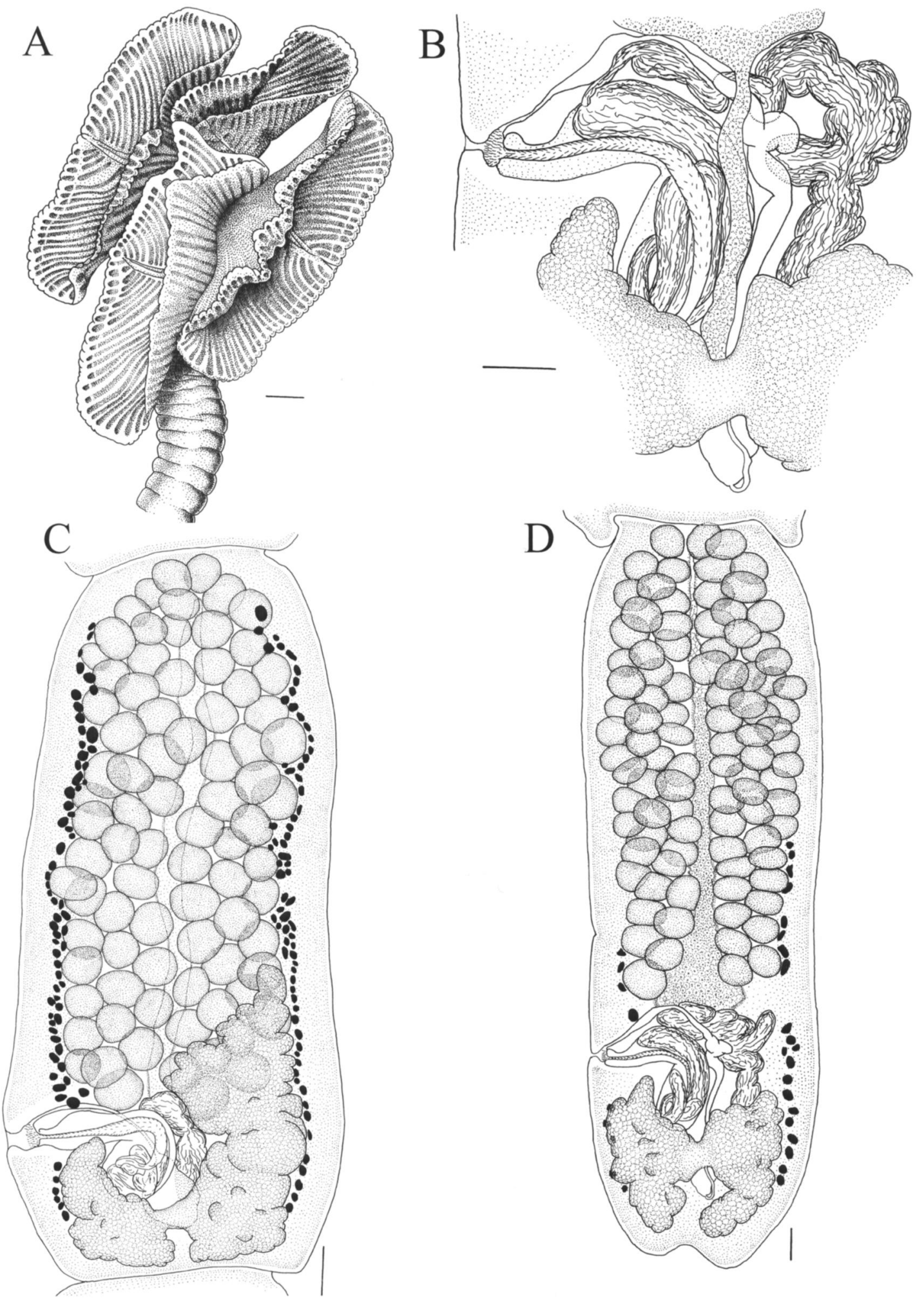

FIGURE 11. Rhinebothroides scorzai. A. Scolex of mature specimens. B. Cirrus sac region. C. Mature proglottis (HWML 21015). D. Gravid proglottis in initial stage of development; note reduction of aporal ovarian lobe (USNPC 75704). Bars $=100 \mu \mathrm{m}$.

4 valid species for this genus: $R$. freitasi, $R$. glandularis, $R$. moralarai, and $R$. scorzai.

This study adds 8 additional host records to the checklists of freshwater potamotrygonids examined for these parasites
(Brooks and Amato, 1992; Brooks, 1995), namely, Plesiotrygon iwamae, Potamotrygon henlei, P. leopoldi, P. ocellata, P. schroederi, $P$. scobina, $P$. signata, and an undescribed species of Potamotrygon from the upper Rio Negro. In addition, we 

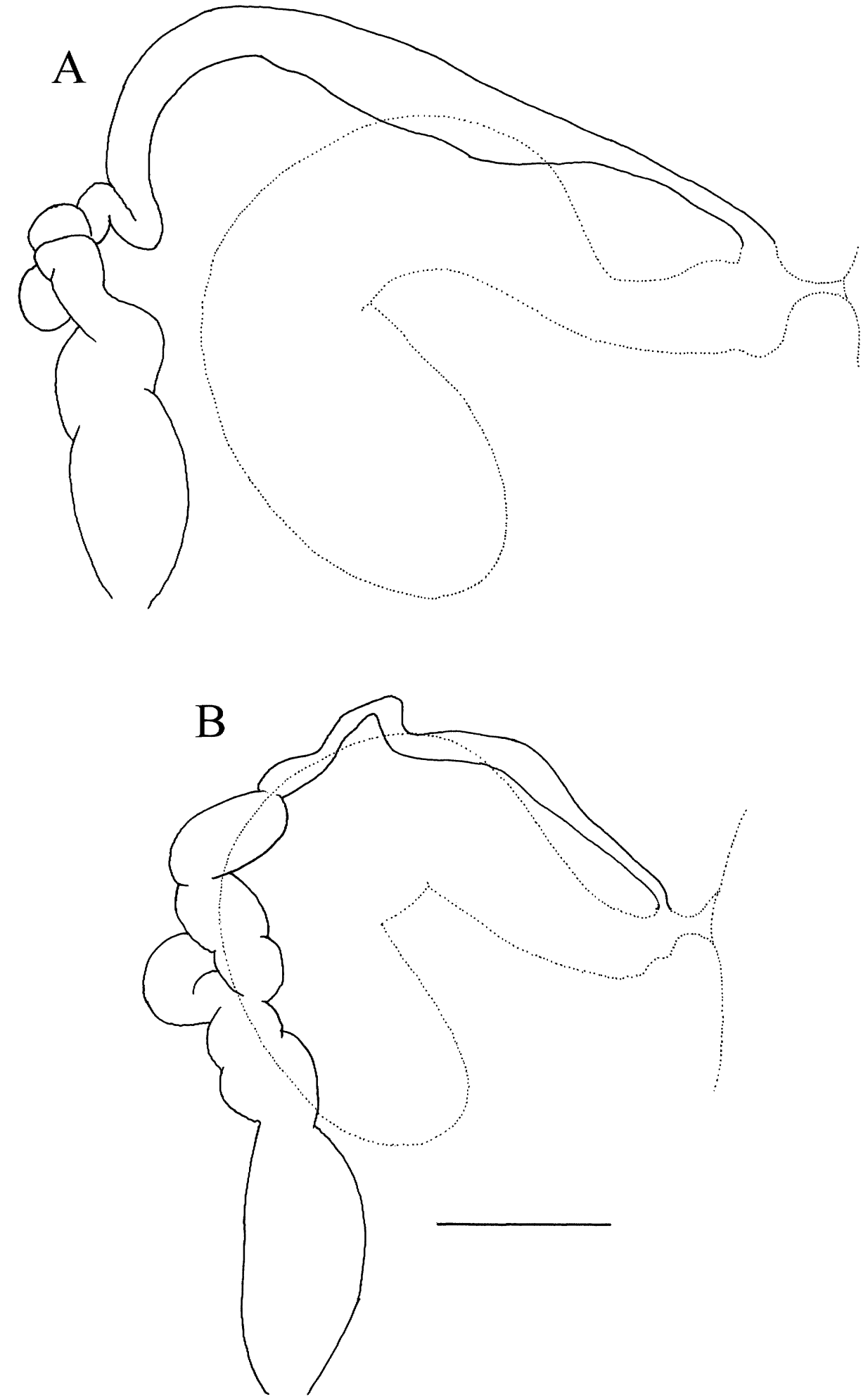

FIGURE 12. Variation in vaginal morphology of Rhinebothroides scorzai. A. Voucher (HWML 21014). B. Voucher (HWML 21015). Bars = $100 \mu \mathrm{m}$. 
add 7 new localities: Rio Parnaíba (northeastern part of Brazil), lower Rio Amazonas, and tributaries of Ilha de Marajó, Rio Tocantins, Rio Xingu, Rio Negro, and Rio Branco were sampled for the first time.

Although this work contributes substantially to the taxonomy of Rhinebothroides, much remains to be done. For example, species of Potamotrygon endemic to the lower Paraná basin, e.g., $P$. histrix, $P$. brachyura, and $P$. castexi, among others, are yet to be examined for parasites. Further efforts in areas and hosts not yet sampled for these organisms will contribute to our knowledge of the biology and diversity of phyllobothriids inhabiting freshwater potamotrygonid and may reveal a clearer picture of how characters vary within species of Rhinebothroides.

\section{ACKNOWLEDGMENTS}

We are indebted to Lisa Nodwell, Jaime Carvalho Jr., Labbish Chao, and the staff and students of the Projeto Piaba, Barcelos, Amazonas, Brazil, for their assistance during the fieldwork in the Amazon region. We are grateful for the hospitality of Maura Kumagay and her family to F.P.L.M. during his stay in Belém do Pará. We gratefully acknowledge Señores Lauriano Sanchez, Juan Sanchez, Hector Sanches, and Andres Gonzales for their help in Puerto Reconquista, Santa Fé, Argentina. This work could not be realized without the help of local fishermen from Argentina and the Amazon region, to whom we express our gratitude. We thank Scott Monks and Anindo Choudhury for reviewing early versions of the manuscript. We are also thankful to Gerhard Pohle for allowing us to use his image analysis software. We thank Cara Gibson for making the final drawings of some scoleces. This work was financially supported by a Conselho Nacional de Desenvolvimento Científico e Tecnológico, Federal Government of Brazil doctorate fellowship to F.P.L.M. and a Natural Sciences and Engineering Council of Canada operating grant A7696 to D.R.B.

\section{LITERATURE CITED}

BROOKS, D. R. 1995. Neotropical freshwater stingrays and their parasites: A tale of an ocean and a river long ago. Journal of Aquariculture and Aquatic Science 7: 52-61.

, AND J. F. R. Amato. 1992. Cestode parasites in Potamotrygon motoro (Matterer) (Chondrichthyes: Potamotrygonidae) from Southwestern Brazil, including Rhinebothroides mclennanae $\mathrm{n}$. $\mathrm{sp}$. (Tetraphyllidea: Phyllobothriidae), and a revised host-parasite checklist for helminths inhabiting neotropical freshwater stingrays. Journal of Parasitology 78: 393-398.

, M. A. MAYes, AND T. B. Thorson. 1981. Systematic review of cestodes infecting freshwater stingrays (Chondrichthyes: Potamotrygonidae) including four new species from Venezuela. Proceeding of the Helminthological Society of Washington 48: 43-64.

, AND T. B. THORsON. 1976. Two tetraphyllidean cestodes from the freshwater stingray Potamotrygon magdalenae Duméril, 1852 (Chondrichthyes: Potamotrygonidae) from Colombia. Journal of Parasitology 62: 943-947.

LóPez-NeYra, C. R., AND C. Diaz-Ungriá. 1958. Cestode de Venezuela. V. Cestodes de Vertebrados Venezolanos (segunda nota). Nova Cientia 23: 1-41.

Marques, F. P. L., D. R. Brooks, AND C. A. Lasso. 2001. Anindobothrium n. gen. (Eucestoda: Tetraphyllidea) inhabiting marine and freshwater potamotrygonid stingrays. Journal of Parasitology 87: 666-672.

Mayes, M. A., D. R. Brooks, And T. B. Thorson. 1981. Two new tetraphyllidean cestodes from Potamotrygon circularis Garman (Chondrichthyes: Potamotrygonidae) in the Itacuaí River, Brazil. Proceedings of the Helminthological Society of Washington 48: $38-42$.

REGO, A. A. 1979. Contribuição ao conhecimento dos helmintos de raias fluviais Paratrygonidae. Revista Brasileira de Biologia 39: 879890.

, AND A. P. L. Dias. 1976. Estudos de cestóides de peixes do Brasil 3a. nota: Cestóides de raias fluviais paratrygonidae. Revista Brasileira de Biologia 36: 941-956.

RosA, R. S. 1985. A systematic revision of the South American freshwater stingrays (Chondrichthyes: Potamotrygonidae). Ph.D. Dissertation. College of William and Mary, Williamsburg, Virginia, $542 \mathrm{p}$. 
APPENDIX I. Measurements obtained for Rhinebothroides freitasi according to host and geographic area.

\begin{tabular}{|c|c|c|c|c|c|}
\hline \multirow[b]{2}{*}{ Population } & \multicolumn{2}{|c|}{ Immature specimens } & \multicolumn{2}{|c|}{ Mature specimens } & \multirow[b]{2}{*}{ No. of loculli } \\
\hline & Size $(\mathrm{mm})$ & No. of segments & Size $(\mathrm{mm})$ & No. of segments & \\
\hline Amazonas* + & 一 & - & - & - & $61-73(67.7 \pm 6, \mathrm{n}=3)$ \\
\hline Upper Solimões $\ddagger \S$ & $4.8-8.3(6.8 \pm 1.5, \mathrm{n}=6)$ & $8-16(11.7 \pm 2.7, \mathrm{n}=6)$ & $7-19(10.6 \pm 4.9, \mathrm{n}=5)$ & $9-20(13.6 \pm 4.4, \mathrm{n}=5)$ & $63-77(71 \pm 7, \mathrm{n}=3)$ \\
\hline Venezuela*⿻ & $5.2-10.2(7.2 \pm 2.2, \mathrm{n}=4)$ & $7-11(10 \pm 2, n=4)$ & $7.1-35.6(20 \pm 11, \mathrm{n}=10)$ & $9-25(16 \pm 6, n=10)$ & $51-69(58.5 \pm 5.6, \mathrm{n}=9)$ \\
\hline Maracaibo||\# & $6.3-9.8(8.4 \pm 1.6, \mathrm{n}=4)$ & $10-13(11 \pm 1, \mathrm{n}=5)$ & 12 & 14 & $49(n=2)$ \\
\hline Corumbađl** & - & - & $7.1-23(14.6 \pm 5.5, \mathrm{n}=6)$ & $7-23(16.7 \pm 5.4, \mathrm{n}=6)$ & $71-73(72 \pm 1.4, \mathrm{n}=2)$ \\
\hline Argentina $\mathscr{l}$ & - & - & $8-17.3(11.3 \pm 2.6, n=11)$ & $8-14(11 \pm 2, \mathrm{n}=11)$ & $>61$ \\
\hline Bela Vista†t & - & 8 & $9-10.8(9.8 \pm 1, \mathrm{n}=3)$ & $10-11(10 \pm 1, \mathrm{n}=3)$ & - \\
\hline BelémII & - & $5(\mathrm{n}=3)$ & $3.6-11.4(6.8 \pm 1.8, \mathrm{n}=21)$ & $5-10(7 \pm 2, \mathrm{n}=21)$ & $53-61(57 \pm 3, \mathrm{n}=8)$ \\
\hline Belém* & - & - & $3.2-9.5(5.8 \pm 2.2, \mathrm{n}=6)$ & $5-10(7 \pm 2, n=8)$ & 57 \\
\hline Marabáł‡ & - & - & $7.5-19.6(13.1 \pm 4.7, \mathrm{n}=6)$ & $8-15(11 \pm 2, n=6)$ & 61 \\
\hline Rio BrancogI & 3.28 & 5 & $4.46-10.5(6.9 \pm 2.2, \mathrm{n}=6)$ & $5-10(7 \pm 2, \mathrm{n}=5)$ & \\
\hline Rio NegroI & $4.2-4.7$ & $6-7(6 \pm 1, n=3)$ & $3-8(5.6 \pm 2, \mathrm{n}=7)$ & $5-9(7 \pm 1.3, \mathrm{n}=7)$ & $51-61(57 \pm 4, n=8)$ \\
\hline Lower Solimões§§ & $12.6-13.1$ & 37,236 & - & - & - \\
\hline Lower Solimões|||| & $5-6.4$ & 41,974 & 12 & 21 & 59 \\
\hline Lower SolimõesII & - & - & $5-6.2(5.7 \pm 0.6, \mathrm{n}=3)$ & 6-7 (7 $\pm 1, \mathrm{n}=3)$ & $59-61$ \\
\hline Venezuela* & - & - & 37,110 & $13-14$ & 61 \\
\hline Xingu\#\# & - & - & $4.3-15.8(7.2 \pm 3.6, \mathrm{n}=11)$ & $5-15(8 \pm 3, n=11)$ & $61-65(63 \pm 2, n=5)$ \\
\hline
\end{tabular}

* Potamotrygon orbignyi.

$\dagger$ Rego (1979) (type specimens).

$\div$ Potamotrygon constellata.

$\S$ Maye et al. (1981).

\| Brooks et al. (1981).

\# Potamotrygon yepezi.

II Potamotrygon motoro.

*** Brooks and Amato (1992).

$\uparrow \dagger$ Potamotrygon falkneri.

杫P. henlei.

$\S \S$ Potamotrygon schroederi.

I|| Potamotrygon scobina.

\#\# Potamotrygon leopoldi.

APPENDIX I. Extended.

\begin{tabular}{|c|c|c|c|c|}
\hline \multirow[b]{2}{*}{ Population } & \multicolumn{2}{|c|}{ Mature proglottides } & \multicolumn{2}{|c|}{ Gravid proglottides } \\
\hline & Width & Genital pore position & Length & Width \\
\hline Amazonas $* \dagger$ & $215.2-242.9$ & $487.9-583.8$ & $2,957-3,419.7(3,151.1 \pm 240.2, \mathrm{n}=3)$ & $299.4-373.4(345.1 \pm 40, n=3)$ \\
\hline Upper Solimõesţ & $357-869.9(515.7 \pm 170.3, \mathrm{n}=7)$ & $231-530(414.3 \pm 102.6, n=6)$ & $1,308.8-3,625.6(2,384.2 \pm 775.1, n=7)$ & $642.8-1,025.7(868.6 \pm 159.2, \mathrm{n}=7)$ \\
\hline Venezuela* & $320-765.7(530.1 \pm 135.9, \mathrm{n}=23)$ & $336-516.3(431.2 \pm 49.5, \mathrm{n}=23)$ & $1,986.5-4,703(3,113.4 \pm 742.6, n=18)$ & $404.1-695.8(564.7 \pm 86.9, \mathrm{n}=18)$ \\
\hline Maracaibo||\# & $539.1-561(551.2 \pm 11.1, \mathrm{n}=3)$ & $252.9-347.6(313.3 \pm 52.4, \mathrm{n}=3)$ & - & - \\
\hline Corumba||** & $244.4-468.1(380.3 \pm 79.1, \mathrm{n}=6)$ & $316.3-450(369.4 \pm 49.6, n=6)$ & $879.2-3,278.5(2,198.8 \pm 842.7, \mathrm{n}=11)$ & $331.8-527.1(452.7 \pm 56.8, \mathrm{n}=11)$ \\
\hline Argentina $a^{\mid}$ & $333-571(434.2 \pm 67.8, \mathrm{n}=18)$ & $277-509.2(397.7 \pm 66.6, \mathrm{n}=18)$ & $2,289-3,244.2(2,808.9 \pm 355.1, \mathrm{n}=11)$ & $430.5-660.2(514.7 \pm 63, n=11)$ \\
\hline Bela Vista†† & $279.5-396(324.7 \pm 62.5, \mathrm{n}=3)$ & $568-672.5(621.4 \pm 43.3, \mathrm{n}=4)$ & $2,387.5$ & 509.4 \\
\hline BelémfI & $199.5-404.3(297.1 \pm 51.9, \mathrm{n}=21)$ & $230-491.8(401.2 \pm 75.7, \mathrm{n}=20)$ & $1,914.2-3,194.7(2,447.2 \pm 373.2, \mathrm{n}=22)$ & $205.4-584.6(352.1 \pm 76.8, \mathrm{n}=22)$ \\
\hline Belém* & 206.2-417.4 (278.8 $\pm 65.3, \mathrm{n}=9)$ & $254.8-557.1(417.7 \pm 114.3, \mathrm{n}=9)$ & $1,633.5-2,972.6(2,136.4 \pm 580.1, \mathrm{n}=4)$ & $238.1-420.4(333.2 \pm 75, n=4)$ \\
\hline Marabáft & $339.5-532.6(429.8 \pm 60.9, \mathrm{n}=10)$ & $388.8-785.8(531.5 \pm 107.4, \mathrm{n}=10)$ & $2,421-3,392.5(2,872.1 \pm 320.1, \mathrm{n}=6)$ & $308.8-528.2(453.8 \pm 82.7, \mathrm{n}=6)$ \\
\hline Rio BrancogI & $274.4-533.1(383.8 \pm 100.3, n=6)$ & $271.6-485.7(355.6 \pm 79.6, n=5)$ & $1,500.6-3,375(2,356.7 \pm 804.9, \mathrm{n}=6)$ & $403.8-514.3(463.6 \pm 50.2, \mathrm{n}=6)$ \\
\hline Rio Negrog [ & $199.7-411.1(299.7 \pm 72, \mathrm{n}=7)$ & $245.6-538.6(390 \pm 87.5, \mathrm{n}=7)$ & $2,588.4-3,593.7(3,048.6 \pm 508, \mathrm{n}=3)$ & $301.9-503.3(405.8 \pm 101, \mathrm{n}=3)$ \\
\hline Lower Solimões §§ & $508.3-620.4(548.1 \pm 43.8, \mathrm{n}=5)$ & $487-587.1(539.2 \pm 37, \mathrm{n}=5)$ & $3,729.5-4,480.7(4,140.6 \pm 294, \mathrm{n}=5)$ & $649.4-873.2(765.2 \pm 82.7, \mathrm{n}=5)$ \\
\hline Lower Solimões|||| & 359.4 & 550.4 & - & - \\
\hline Lower Solimões" & $209.1-251.8(236.5 \pm 23.8, \mathrm{n}=3)$ & $277-352.8(307.7 \pm 39.9, \mathrm{n}=3)$ & $1,747.4-2,389.7(2,022.3 \pm 300.3, n=4)$ & $279.3-450.6(346.6 \pm 76.2, n=4)$ \\
\hline Venezuela* & $368.1-433.4(399.8 \pm 25.8, \mathrm{n}=6)$ & $335.3-505.4(386.3 \pm 63.7, \mathrm{n}=6)$ & $1,431.8-2,284.9(1,911.1 \pm 436.2, \mathrm{n}=3)$ & $400-466.1(439.2 \pm 34.7, \mathrm{n}=3)$ \\
\hline Xingu\#\# & $197.1-387.7(255.8 \pm 56.9, \mathrm{n}=10)$ & $308.8-512.5(393.3 \pm 65.7, \mathrm{n}=10)$ & $1,864.8-2,818.1(2,238.4 \pm 347, \mathrm{n}=10)$ & $235.9-385.5(279.4 \pm 44, \mathrm{n}=10)$ \\
\hline
\end{tabular}


APPENDIX I. Extended.

\begin{tabular}{|c|c|c|c|}
\hline \multicolumn{3}{|c|}{ Immature proglottides } & \multirow{2}{*}{$\begin{array}{l}\text { Mature proglottides } \\
\text { Length }\end{array}$} \\
\hline Length & Width & Genital pore position & \\
\hline- & - & - & $2,358.1-3,110.9$ \\
\hline $877.2-1,962.1(1,310.2 \pm 290.8, \mathrm{n}=16)$ & $223.3-543.2(392.1 \pm 95.4, \mathrm{n}=16)$ & $229.2-470.7(318.1 \pm 76.8, \mathrm{n}=16)$ & $1,062-2,052(1,780.2 \pm 341.9, \mathrm{n}=7)$ \\
\hline $960.1-1,961.9(1,426.1 \pm 268.1 \mathrm{n}=15)$ & $227.3-690.3(386.9 \pm 119.7, \mathrm{n}=15)$ & $260-437(340.8 \pm 62.5, \mathrm{n}=15)$ & $1,477.1-2,506(2,010 \pm 286.4, \mathrm{n}=23)$ \\
\hline $639.9-1,527(1,169.8 \pm 253.1, \mathrm{n}=15)$ & $197-574.1(408.1 \pm 110, \mathrm{n}=15)$ & $185.6-435.9(286.7 \pm 60.3, \mathrm{n}=15)$ & $1,031.9-1,540.7(1,324.6 \pm 262.9, \mathrm{n}=3)$ \\
\hline- & - & - & $1,078.4-2,010.6(1,475.4 \pm 390.5, \mathrm{n}=6)$ \\
\hline - & - & - & $1,374.6-2,590.9(1,888 \pm 328.5, \mathrm{n}=18)$ \\
\hline $1,494.5-2,018.4$ & $346.5-480.3$ & $379-614$ & $1,986.6-3,585.1(2,912.1 \pm 729.7, n=4)$ \\
\hline $861.7-2,709.2(1,372.6 \pm 558.5, \mathrm{n}=9)$ & $178.6-308.2(257.2 \pm 42.7, \mathrm{n}=9)$ & $235-535.7(353.9 \pm 97.3, \mathrm{n}=9)$ & $1,023-2,116.5(1,653.4 \pm 320.2, \mathrm{n}=21)$ \\
\hline $574.1-1,511.9(1,176.1 \pm 349.7, \mathrm{n}=6)$ & $195.1-275.4(225.6 \pm 27, \mathrm{n}=6)$ & $132.1-398.2(292.2 \pm 92, \mathrm{n}=6)$ & $995.8-2,184.5(1,706.5 \pm 409.1, \mathrm{n}=9)$ \\
\hline $1,307.5-1,519.4$ & $289.2-359.8$ & $323-442.8$ & $1,721.2-2,669.1(2,189.2 \pm 291.7, \mathrm{n}=10)$ \\
\hline- & - & - & $1,132.8-1,985.5(1,515.4 \pm 309.5, \mathrm{n}=6)$ \\
\hline $1,961.2$ & 145.8 & 449.7 & $1,018.9-2,277.3(1,710.7 \pm 472.2, \mathrm{n}=7)$ \\
\hline - & - & - & $2,593.6-3,355.5(2,956.6 \pm 345.6, \mathrm{n}=5)$ \\
\hline $1,050-1,825$ & $28-350$ & $320-450$ & 1,996 \\
\hline- & - & - & $1,184.6-1,508.2(1,299.5 \pm 181.1, \mathrm{n}=3)$ \\
\hline- & - & - & $1,315.5-2,343.5(1,661.2 \pm 396.1, \mathrm{n}=6)$ \\
\hline $966.8-2,096.1(1,323.1 \pm 457.4, \mathrm{n}=5)$ & $168.8-393.1(280.6 \pm 85.2, \mathrm{n}=5)$ & $221.9-539.6(331.7 \pm 125.5, \mathrm{n}=5)$ & $1,136.5-2,055.1(1,501.7 \pm 333, n=10)$ \\
\hline
\end{tabular}

APPENDIX I. Extended.

\begin{tabular}{|c|c|c|c|c|c|}
\hline \multirow{2}{*}{$\begin{array}{l}\text { Gravid proglottides } \\
\text { Genital pore position }\end{array}$} & \multicolumn{3}{|c|}{ Testes number } & \multicolumn{2}{|c|}{ Testes dimensions } \\
\hline & Preporal & Antiporal & Total & Length & Width \\
\hline $473-612.4(534.8 \pm 71, \mathrm{n}=3)$ & 25 & 27 & 52 & $53.8-75(60.1 \pm 6.8, \mathrm{n}=10)$ & $47.9-59.3(54.3 \pm 3.2, \mathrm{n}=10)$ \\
\hline $275.2-890.9(476 \pm 207.3, \mathrm{n}=7)$ & $17-38(29 \pm 6 ; n=24)$ & $21-47(33 \pm 7, \mathrm{n}=24)$ & $38-79(62 \pm 13, n=24)$ & $36.5-75.4(58.4 \pm 8.6, \mathrm{n}=35)$ & $32.1-56.8(47.3 \pm 6.9, \mathrm{n}=35)$ \\
\hline $345.3-771.2(527.9 \pm 97.7, \mathrm{n}=18)$ & $20-33(25 \pm 3, \mathrm{n}=43)$ & $20-31(26 \pm 3, n=43)$ & $42-61(51 \pm 5, n=43)$ & $45.2-91(68.3 \pm 10.7, \mathrm{n}=95)$ & $43.4-86(63.9 \pm 9.7, \mathrm{n}=95)$ \\
\hline - & $20-34(26 \pm 4, n=16)$ & $15-31(25 \pm 4, n=16)$ & $35-63(51 \pm 7, \mathrm{n}=16)$ & $45.1-131.1(75.6 \pm 24.3, \mathrm{n}=25)$ & $43.4-89.3(59.4 \pm 11.4, \mathrm{n}=25)$ \\
\hline $250.8-563.5(443.6 \pm 84.1, \mathrm{n}=11)$ & $15-30(21 \pm 4, n=16)$ & $13-31(21 \pm 5, \mathrm{n}=16)$ & $28-59(42 \pm 8, n=16)$ & $34.9-80.8(57 \pm 9.2, \mathrm{n}=30)$ & $27.7-70.3(44 \pm 8.9, \mathrm{n}=30)$ \\
\hline $383.3-686.2(542.7 \pm 94, \mathrm{n}=11)$ & $11-25(18 \pm 3, \mathrm{n}=28)$ & $14-26(20 \pm 3, \mathrm{n}=28)$ & $29-50(38 \pm 5, \mathrm{n}=28)$ & $47.7-78.9(67.2 \pm 6.5, \mathrm{n}=50)$ & $47.4-74.1(58.8 \pm 7.2, \mathrm{n}=50)$ \\
\hline 663.6 & $24-29(28 \pm 2, \mathbf{n}=8)$ & $28-35(30 \pm 2, n=8)$ & $53-64(58 \pm 3, n=8)$ & $61-84.1(72.6 \pm 5.8, \mathrm{n}=15)$ & $42.8-59.4(53.5 \pm 5.5, \mathrm{n}=15)$ \\
\hline $431.6-689.9(519.3 \pm 62.7, \mathrm{n}=22)$ & $9-25(17 \pm 3, n=54)$ & $11-26(18 \pm 3, n=54)$ & $21-51(35 \pm 6, n=54)$ & $44-84.4(65.7 \pm 8.7, \mathrm{n}=113)$ & $37.3-76.9(54.1 \pm 9, \mathrm{n}=113)$ \\
\hline $434.4-531.4(491 \pm 40.7, \mathrm{n}=4)$ & $14-21(17 \pm 2, \mathrm{n}=16)$ & $14-21(17 \pm 2, n=16)$ & $29-42(34 \pm 3, n=16)$ & $45.1-90.1(62.2 \pm 9.5, \mathrm{n}=60)$ & $37.5-79.7(52.1 \pm 10.7, \mathrm{n}=60)$ \\
\hline $568.7-672(616.9 \pm 38.4, \mathrm{n}=6)$ & $16-35(26 \pm 6, \mathrm{n}=17)$ & $17-36(26 \pm 6, n=17)$ & $33-68(52 \pm 12, \mathrm{n}=17)$ & $63-105.6(80.5 \pm 10.4, \mathrm{n}=40)$ & $53-90.1(71.3 \pm 9, \mathrm{n}=40)$ \\
\hline $394.3-640(506.6 \pm 115.1, \mathrm{n}=6)$ & $17-26(20 \pm 3, n=8)$ & $16-27(21 \pm 4, n=8)$ & $33-53(41 \pm 6.4, \mathrm{n}=8)$ & $53.8-89.5(70.7 \pm 11.8, \mathrm{n}=25)$ & $41.5-85.5(60.8 \pm 12.3, \mathrm{n}=25)$ \\
\hline $553.1-623.6(590 \pm 35.4, \mathrm{n}=3)$ & $10-23(18 \pm 4, n=15)$ & $10-27(18 \pm 5, \mathrm{n}=15)$ & $20-48(36 \pm 8, n=15)$ & $56.1-99.8(75.6 \pm 11.5, \mathrm{n}=30)$ & $46.3-74.8(57.2 \pm 6.7, \mathrm{n}=30)$ \\
\hline $563.4-735(644.8 \pm 65.1, \mathrm{n}=5)$ & $24-36(30 \pm 4, \mathrm{n}=11)$ & $26-37(31 \pm 3, \mathrm{n}=11)$ & $50-69(61 \pm 7, \mathrm{n}=11)$ & $83.6-113.4(93.8 \pm 8.7, \mathrm{n}=10)$ & $78.4-91.4(84.3 \pm 4.4, \mathrm{n}=10)$ \\
\hline - & $20-25(23 \pm 2, \mathrm{n}=7)$ & $19-24(21 \pm 2, \mathrm{n}=7)$ & $39-47(44 \pm 3, n=7)$ & $66.8-90.2(78.7 \pm 9, \mathrm{n}=10)$ & $45.6-75.4(58.4 \pm 8.8, \mathrm{n}=10)$ \\
\hline $351.6-540(475.1 \pm 84.2, n=4)$ & $17-20(19 \pm 1, n=6)$ & $14-20(17 \pm 3, \mathrm{n}=6)$ & $32-40(36 \pm 4, n=6)$ & $42.7-63.6(52.6 \pm 5, n=15)$ & $32.2-51.5(42 \pm 6.1, \mathrm{n}=15)$ \\
\hline $381.9-551.1(466.5 \pm 119.6, \mathrm{n}=2)$ & $16-22(20 \pm 2, n=10)$ & $17-24(20 \pm 2, \mathrm{n}=10)$ & $33-46(40 \pm 4, n=10)$ & $47.1-74.8(63.2 \pm 7.3, \mathrm{n}=25)$ & $37.6-70(50.6 \pm 8, n=25)$ \\
\hline $393.5-575(483.8 \pm 52, \mathrm{n}=10)$ & $11-24(17 \pm 3, \mathrm{n}=28)$ & $11-24(17 \pm 4, n=28)$ & $23-46(34 \pm 7, \mathrm{n}=28)$ & $43.7-81.4(59.6 \pm 9.3, \mathrm{n}=55)$ & $30.1-69.6(49.8 \pm 8.7, \mathrm{n}=55)$ \\
\hline
\end{tabular}


APPENDIX I. Extended.

\begin{tabular}{|c|c|c|c|c|}
\hline \multirow[b]{2}{*}{ Population } & \multicolumn{2}{|c|}{ Cirrus sac in mature proglottides } & \multicolumn{2}{|c|}{ Cirrus sac in gravid proglottides } \\
\hline & Length & Width & Length & Width \\
\hline Amazonas* + & $268.3-284$ & $50.9-64.6$ & $322.2-396.2(366.3 \pm 39, \mathrm{n}=3)$ & $81.2-96.3(88.2 \pm 7.6, \mathrm{n}=3)$ \\
\hline Upper Solimõesł\& & $260.4-429.8(302.4 \pm 63.7, \mathrm{n}=6)$ & $37.2-77.7(59.9 \pm 17.8, \mathrm{n}=6)$ & $283.4-576.3(425 \pm 140.3, \mathrm{n}=4)$ & $51.8-111.4(76.8 \pm 26.3, n=4)$ \\
\hline Venezuela*\| & $221.7-430.2(313.3 \pm 58.9, \mathrm{n}=18)$ & $47.2-95.4(68.7 \pm 11.9, \mathrm{n}=18)$ & $339.5-1,491.1(542.1 \pm 260, \mathrm{n}=16)$ & $66.1-236(97.8 \pm 39.2, \mathrm{n}=16)$ \\
\hline Maracaibo\|\#\# & $318.1-341.7(331.2 \pm 12, \mathrm{n}=3)$ & $77.3-86.2(80.5 \pm 5, \mathrm{n}=3)$ & - & - \\
\hline CorumbaI[ $* *$ & $275.6-346.8(310.6 \pm 26.7, \mathrm{n}=6)$ & $42-60.1(50.6 \pm 7.2, \mathrm{n}=6)$ & $331.9-493(403.4 \pm 47.9, \mathrm{n}=11)$ & $64.8-112.7(86.1 \pm 17, \mathrm{n}=11)$ \\
\hline ArgentinađI & $240.3-414.9(321.5 \pm 52.3, \mathrm{n}=18)$ & $49.7-84.4(68.1 \pm 11.2, \mathrm{n}=18)$ & $413.8-548.1(485.4 \pm 36.4, \mathrm{n}=11)$ & $89.9-118.9(102.7 \pm 8.6, \mathrm{n}=11)$ \\
\hline Bela Vista $\dagger$ & $323.3-389.3(358.3 \pm 29.7, n=4)$ & $79.5-105.5(92.3 \pm 10.8, \mathrm{n}=4)$ & 389.6 & 132.1 \\
\hline BelémII & $184.6-343.1(278 \pm 47.1, \mathrm{n}=17)$ & $44.9-73.6(59.5 \pm 9.1, \mathrm{n}=17)$ & $298.5-472(390.1 \pm 49.7, \mathrm{n}=21)$ & $60.9-120.5(84.2 \pm 14.3, \mathrm{n}=21)$ \\
\hline Belém* & $241.6-345.2(285 \pm 37.5, \mathrm{n}=8)$ & $61.4-82.5(69.4 \pm 6.8, \mathrm{n}=8)$ & $319.3-474.7(377.7 \pm 67.4, n=4)$ & $72.2-87.6(80.2 \pm 6.4, \mathrm{n}=4)$ \\
\hline Marabáł: & $290.1-432.6(352 \pm 50, \mathrm{n}=9)$ & $68-93.8(80.7 \pm 8, \mathrm{n}=9)$ & $392.8-603.7(478.5 \pm 76, n=6)$ & $78.3-107.6(92.7 \pm 9.8, \mathrm{n}=6)$ \\
\hline Rio Brancofl & $246.5-395.5(341.5 \pm 82.6, \mathrm{n}=3)$ & $65.5-96.7(76.3 \pm 17.7, \mathrm{n}=3)$ & $314.6-521.8(423.9 \pm 94.4, \mathrm{n}=5)$ & $86.1-119.7(101.2 \pm 14, n=5)$ \\
\hline Rio Negrofl & $258.1-348.8(314 \pm 39, n=4)$ & $57.4-81.7(65.8 \pm 11.4, \mathrm{n}=4)$ & $363.7-490.5(427.2 \pm 63.4, \mathrm{n}=3)$ & $87.1-95.3(91.1 \pm 4.1, \mathrm{n}=3)$ \\
\hline Lower Solimões§§ & $337.3-423.6(384.6 \pm 39.9, \mathrm{n}=5)$ & $69.6-90(80.7 \pm 8.6, \mathrm{n}=5)$ & $472.9-632.3(537.2 \pm 65, n=5)$ & $95.9-146.3(120.9 \pm 19.7, \mathrm{n}=5)$ \\
\hline Lower Solimões|||| & $296.7-321$ & $63.2-77.6$ & - & - \\
\hline Lower SolimõesII & $161-193$ & $41-44$ & $221.5-324.2(292 \pm 48, \mathrm{n}=4)$ & $55.6-72.4(65 \pm 7.4, \mathrm{n}=4)$ \\
\hline Venezuela* & $204.2-342.4(248 \pm 46.6, n=7)$ & $56.2-88.4(69.4 \pm 11, \mathrm{n}=7)$ & $316.3-353.5(336.4 \pm 15.5, n=4)$ & $70.7-75.6(73.1 \pm 2, \mathrm{n}=4)$ \\
\hline Xingu\#\# & $236.4-438.6(286 \pm 63, n=9)$ & $49.4-83.7(60.1 \pm 10, \mathrm{n}=9)$ & $310.8-485.2(398.5 \pm 49, \mathbf{n}=10)$ & $55.1-95.8(78.7 \pm 13, \mathrm{n}=10)$ \\
\hline
\end{tabular}

APPENDIX II. Measurements obtained for Rhinebothroides glandularis according to host and geographic area.

\begin{tabular}{|c|c|c|c|c|c|}
\hline \multirow[b]{2}{*}{ Population } & \multicolumn{2}{|c|}{ Immature spp. } & \multicolumn{2}{|c|}{ Mature spp. } & \multirow[b]{2}{*}{ No. of loculli } \\
\hline & Size $(\mathrm{mm})$ & No. of segments & Size (mm) & No. of segments & \\
\hline Venezuela*† & - & - & $9.6-28.4(20 \pm 6, \mathrm{n}=13)$ & $17-34(30 \pm 5, \mathrm{n}=13)$ & $49-53(51 \pm 2.8, \mathrm{n}=2)$ \\
\hline Corumbáł§ & - & - & $7.6-14.6(11.3 \pm 2.7, \mathrm{n}=8)$ & $12-23(17.7 \pm 4.4, \mathrm{n}=8)$ & 53 \\
\hline Rio Brancoł & - & - & $7.1-9.4$ & 12 & - \\
\hline Rio Negro $\ddagger$ & $4.5-5.8(5.2 \pm 1, \mathrm{n}=3)$ & $10-14(12 \pm 2, \mathrm{n}=3)$ & $5.9-10.5(7.9 \pm 1.6, \mathrm{n}=6)$ & $12-17(14 \pm 2, \mathrm{n}=6)$ & $59-65(62.5 \pm 3, \mathrm{n}=4)$ \\
\hline Rio Negro* & - & - & 6.2 & 13 & 67 \\
\hline Solimões $\ddagger$ & - & - & $5.7-21.8(11.4 \pm 4.9, \mathrm{n}=19)$ & $9-22(15.7 \pm 4.2, \mathrm{n}=19)$ & $57-63(59 \pm 3, \mathrm{n}=3)$ \\
\hline Solimões\| & - & - & 15.1 & 21 & - \\
\hline Marabá\# & - & - & $11.1-24.1(18 \pm 4.9, \mathrm{n}=9)$ & $18-28(23 \pm 3, \mathrm{n}=9)$ & $55-63(60.3 \pm 4.6, n=3)$ \\
\hline Belém‡ & $4.4-6(5 \pm 1, \mathrm{n}=3)$ & $9-10(9.5 \pm 1, \mathrm{n}=2)$ & $4.5-18(10.1 \pm 3.7, \mathrm{n}=18)$ & $8-18(13.5 \pm 3, \mathrm{n}=18)$ & $57-71(61.6 \pm 3.7, \mathrm{n}=10)$ \\
\hline Belém* & - & - & $8.2-13.5$ & $14-18$ & - \\
\hline Argentina $\neq$ & - & - & $9-20(13 \pm 4, n=9)$ & $13-21(17 \pm 3, \mathrm{n}=9)$ & $59-61$ \\
\hline Teresinaql & - & - & $8.7-22$ & $19-31$ & 59 \\
\hline Venezuela** & $3.5-3.8$ & $7-15$ & - & - & - \\
\hline
\end{tabular}

* Potamotrygon orbignyi.

$\dagger$ Brooks et al. (1981).

$\$$ Potamotrygon motoro.

$\S$ Brooks and Amato (1992).

\| Potamotrygon scobina.

\# Potamotrygon henlei.

II Potamotrygon signata

** Potamotrygon sp. 
APPENDIX I. Extended.

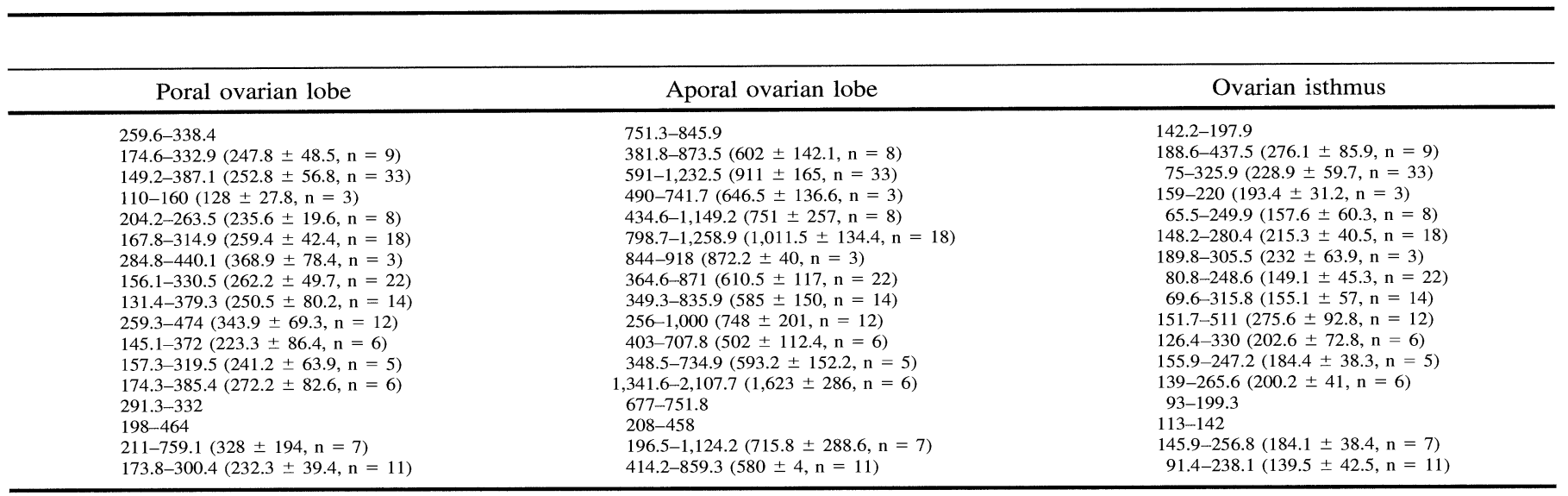

APPENDIX II. Extended.

\begin{tabular}{|c|c|c|c|}
\hline \multicolumn{3}{|c|}{ Immature proglottides } & \multirow{2}{*}{$\begin{array}{l}\text { Mature proglottides } \\
\text { Length }\end{array}$} \\
\hline Length & Width & Genital pore position & \\
\hline $1,080.8-1,528.1(1,319 \pm 225.1, \mathrm{n}=3)$ & $326.8-509.9(411.2 \pm 92.4, \mathrm{n}=3)$ & $327-452(403.5 \pm 67.1, \mathrm{n}=3)$ & $1,019.5-2,125(1,675 \pm 284, \mathrm{n}=27)$ \\
\hline $1,190.5-1,579.3(1,445.6 \pm 221, \mathrm{n}=3)$ & $160.5-260.9(221.6 \pm 53.6, \mathrm{n}=3)$ & $302-447(393.4 \pm 79.6, \mathrm{n}=3)$ & $1,120.5-1,529.2(1,299 \pm 141, \mathrm{n}=6)$ \\
\hline- & - & - & $1,219.4-1,488.2(1,357.4 \pm 134.5, \mathrm{n}=3)$ \\
\hline $1,094.2-1,533.3(1,313.7 \pm 310.5, \mathrm{n}=2)$ & $252-296.3(274.1 \pm 31.3, \mathrm{n}=2)$ & $324-479.1(401.5 \pm 109.7, \mathrm{n}=2)$ & $738.6-1,413(1,138.5 \pm 278.3, \mathrm{n}=8)$ \\
\hline - & - & - & 1,130 \\
\hline - & - & - & $963.1-2,158.5(1,437 \pm 254.7, \mathrm{n}=26)$ \\
\hline - & - & - & $1,822.1-1,825.7$ \\
\hline $1,385.6$ & 288.6 & 428 & $1,021.4-1,843.7(1,445.9 \pm 228.4, \mathrm{n}=13)$ \\
\hline $819.6-1,616.4(1,211.2 \pm 309.6, n=6)$ & $144.6-380.9(270 \pm 85.3, \mathrm{n}=6)$ & $259.8-608.5(412.9 \pm 136.1, \mathrm{n}=6)$ & $1,106.1-1,926.9(1,495.8 \pm 193.2, \mathrm{n}=28)$ \\
\hline $1,142.8$ & 213.1 & 353 & $1,332-1,383$ \\
\hline- & - & - & $1,244-1,759(1,511 \pm 174, \mathrm{n}=12)$ \\
\hline - & - & - & $655.7-1,319.5(1,038.7 \pm 343.5, \mathrm{n}=3)$ \\
\hline- & - & - & - \\
\hline
\end{tabular}


APPENDIX II. Extended.

\begin{tabular}{|c|c|c|c|c|}
\hline \multirow[b]{2}{*}{ Population } & \multicolumn{2}{|c|}{ Mature proglottides } & \multicolumn{2}{|c|}{ Gravid proglottides } \\
\hline & Width & Genital pore position & Length & Width \\
\hline Venezuela*† & $375.4-568(457.3 \pm 55, \mathrm{n}=27)$ & $306-618.3(466.4 \pm 79.3, \mathrm{n}=27)$ & $1,660.3-2,578.7(2,041.5 \pm 274.3, \mathrm{n}=18)$ & $448.1-662.1(538.8 \pm 54.5, \mathrm{n}=18)$ \\
\hline Corumbáł§ & $215.4-379.1(293.2 \pm 61.3, \mathrm{n}=6)$ & $335-376.3(353.4 \pm 16.6, n=6)$ & $1,533.6-1,974(1,735.4 \pm 160.1, n=11)$ & $271.2-466.6(364.1 \pm 65, \mathrm{n}=11)$ \\
\hline Rio Branco $\neq$ & $339.9-445.2(410.1 \pm 60.8, \mathrm{n}=3)$ & $395.1-489.9(429.5 \pm 52.5, \mathrm{n}=3)$ & $2,094.5$ & 435.4 \\
\hline Rio Negro $\leftarrow$ & $277.9-413.8(354.6 \pm 52.9, \mathrm{n}=8)$ & $190-819.3(447 \pm 182.8, \mathrm{n}=8)$ & $1,170.8-1,796.1(1,450 \pm 203.8, \mathrm{n}=6)$ & $386.3-490.6(427.2 \pm 43.1, \mathrm{n}=6)$ \\
\hline Rio Negro* & 370 & 380 & - & - \\
\hline Solimões: & $271.5-599.1(393.7 \pm 71.7, \mathrm{n}=26)$ & $293.1-560.1(413.7 \pm 71.1, \mathrm{n}=26)$ & $1,245.9-2,392.7(1,708.2 \pm 274.2, \mathrm{n}=20)$ & $381.9-659.6(485.6 \pm 76.1, \mathrm{n}=20)$ \\
\hline Solimões\| & $346.7-483.1$ & $610.6-625$ & $1,687.8$ & 538.6 \\
\hline Marabá\# & $276.5-471.9(366 \pm 72, \mathrm{n}=13)$ & $302-523.7(426.7 \pm 64.4, n=13)$ & $1,189.3-2,292.5(1,692.9 \pm 225.7, \mathrm{n}=25)$ & $309.9-586.4(465.6 \pm 71.6, \mathrm{n}=25)$ \\
\hline Belém $\ddagger$ & $197.5-484.5(331.2 \pm 74.2, \mathrm{n}=28)$ & $344-543.9(456.8 \pm 58.2, \mathrm{n}=28)$ & $1,471.3-2,479(1,897.6 \pm 251.2, n=22)$ & $262.9-596.6(442.2 \pm 69.6, \mathrm{n}=22)$ \\
\hline Belém* & $264-321.5$ & $399.6-580$ & $1,418.6-1,594.3$ & $418.8-424$ \\
\hline Argentina & $229-443(352 \pm 63, n=12)$ & $340-579(429 \pm 66, \mathrm{n}=12)$ & $1,572-2,010(1,769 \pm 133, \mathrm{n}=13)$ & $389-574(461 \pm 50, \mathrm{n}=13)$ \\
\hline Teresinat & $435.6-510.7(484.4 \pm 42.3, n=3)$ & $199-315.1(272.8 \pm 64.1, \mathrm{n}=3)$ & $1,138-1,654.7$ & $737.6-766.5$ \\
\hline Venezuela*** & - & - & - & - \\
\hline
\end{tabular}

APPENDIX II. Extended.

Cirrus sac in mature proglottides

\begin{tabular}{|c|c|c|c|c|}
\hline Population & Length & Width & Length & Width \\
\hline Venezuela*t & $215-394.4(328 \pm 51, \mathrm{n}=15)$ & $69.9-144(93 \pm 11, \mathrm{n}=15)$ & $318.6-469.1(390.1 \pm 47.6, \mathrm{n}=18)$ & $70.3-126.3(102.8 \pm 17.1, \mathrm{n}=18)$ \\
\hline Corumbá:\$ & $187.3-273.9(232 \pm 32.6, \mathrm{n}=7)$ & $54.3-65.5(60.7 \pm 4.1, \mathrm{n}=7)$ & $249.1-367.1(315 \pm 31.4, \mathrm{n}=11)$ & $58.7-90.2(71.6 \pm 9.2, \mathrm{n}=11)$ \\
\hline Rio Branco & $255.3-266.3$ & $69.4-74.6$ & 386.9 & 119.1 \\
\hline Rio Negro & $236.6-311.1(264.3 \pm 29.6, \mathrm{n}=7)$ & $60.2-93.7(73.3 \pm 12.4, \mathrm{n}=7)$ & $278.4-388.5(346.1 \pm 42.1, \mathrm{n}=6)$ & $86-114.7(99.5 \pm 12.5, \mathrm{n}=6)$ \\
\hline Rio Negro* & 234.6 & 68.4 & - & - \\
\hline Solimões $¥$ & $195-403.2(293.2 \pm 58.8, \mathrm{n}=22)$ & $39.7-97.6(76.1 \pm 15.6, \mathrm{n}=22)$ & $261.2-507.5(383.9 \pm 64.7, \mathrm{n}=20)$ & 63.9-142.6 $(101 \pm 17.3, \mathrm{n}=20)$ \\
\hline Solimões\| & $317.3-351.9$ & $89.2-105.3$ & 413.3 & 118.8 \\
\hline Marabá\# & $222.4-339(261.6 \pm 36.2, \mathrm{n}=13)$ & $53.7-84.6(72.5 \pm 10.7, \mathrm{n}=13)$ & $237.3-422.5(335.7 \pm 51.4, \mathrm{n}=25)$ & $79.1-125.8(97.8 \pm 13.6, \mathrm{n}=25)$ \\
\hline Belém $\ddagger$ & $201.8-408.8(267 \pm 51, \mathrm{n}=25)$ & $57.1-108.1(79.8 \pm 12.6, \mathrm{n}=25)$ & $196.7-489.4(373.75 \pm 66.6, n=22)$ & $62.1-134.2(103.5 \pm 17.1, \mathrm{n}=22)$ \\
\hline Belém* & $227.4-247.3$ & $47.2-63.6$ & 323.9 & 112.2 \\
\hline Argentina $\leftarrow$ & $207-305(267 \pm 34, \mathrm{n}=10)$ & $61-83(72 \pm 8, \mathrm{n}=10)$ & $290-437(362 \pm 44, \mathrm{n}=13)$ & $78-108(90 \pm 9, \mathrm{n}=13)$ \\
\hline Teresinatl & $338-346$ & $62.5-100.8$ & $396.9-453.5$ & $110.8-133.2$ \\
\hline Venezuela** & - & - & - & - \\
\hline
\end{tabular}


APPENDIX II. Extended.

\begin{tabular}{|c|c|c|c|c|c|}
\hline \multirow{2}{*}{$\begin{array}{l}\text { Gravid proglottides } \\
\text { Genital pore position }\end{array}$} & \multicolumn{3}{|c|}{ Testes number } & \multicolumn{2}{|c|}{ Testes diameter } \\
\hline & Preporal & Antiporal & Total & Length & Width \\
\hline $439.8-615.6(518.9 \pm 54, \mathrm{n}=18)$ & $16-29(22 \pm 3, \mathrm{n}=48)$ & $15-27(22 \pm 2, n=48)$ & $34-53(43 \pm 4, n=48)$ & $38.9-87.8(70 \pm 9.7, \mathrm{n}=90)$ & $40.4-79.6(61.5 \pm 8.3, \mathrm{n}=90)$ \\
\hline $415.2-564.3(478.9 \pm 44.6, \mathrm{n}=11)$ & $12-21(16 \pm 3, \mathrm{n}=23)$ & $11-21(15 \pm 3, \mathrm{n}=23)$ & $23-41(31 \pm 5, \mathrm{n}=23)$ & $29.3-68.8(45.4 \pm 9.8, \mathrm{n}=40)$ & $29.9-49.2(38.2 \pm 4.7, \mathrm{n}=40)$ \\
\hline 560.3 & $14-19(16 \pm 2, n=4)$ & $13-16(15 \pm 1, \mathrm{n}=4)$ & $29-35(31 \pm 3, \mathrm{n}=4)$ & $59.6-94.7(70.7 \pm 11.5, \mathrm{n}=10)$ & $41.8-58.3(54.1 \pm 4.9, \mathrm{n}=10)$ \\
\hline $339.8-467.8(395.3 \pm 44.1, \mathrm{n}=6)$ & $13-34(19 \pm 4, n=21)$ & $13-23(18 \pm 2, \mathrm{n}=21)$ & $27-50(37 \pm 5, \mathrm{n}=21)$ & $50.2-75.7(60.6 \pm 7.5, \mathrm{n}=25)$ & $30.8-69.4(51 \pm 10.2, \mathrm{n}=25)$ \\
\hline- & $17-22(19 \pm 3, \mathrm{n}=3)$ & $20-25(22 \pm 3, \mathrm{n}=3)$ & $37-47(41 \pm 6, n=3)$ & - & - \\
\hline $354-656(481.7 \pm 68, \mathrm{n}=20)$ & $11-24(17.5 \pm 3, \mathrm{n}=61)$ & $10-25(18 \pm 3, \mathrm{n}=61)$ & $21-48(35 \pm 5, \mathrm{n}=61)$ & $50.4-97.5(67.5 \pm 9.7, \mathrm{n}=103)$ & $36.2-71.7(54.8 \pm 7.6, \mathrm{n}=103)$ \\
\hline 571 & $13-16(15 \pm 2, \mathrm{n}=3)$ & $14-18(16 \pm 2, \mathrm{n}=3)$ & $27-34(31 \pm 4, \mathrm{n}=3)$ & $78.4-99.6(87.72 \pm 7.9, \mathrm{n}=5)$ & $62.5-74.5(69.56 \pm 4.5, \mathrm{n}=5)$ \\
\hline $347-633(471.9 \pm 51.9, \mathrm{n}=25)$ & $11-26(18 \pm 3, \mathrm{n}=35)$ & $11-25(19 \pm 3, \mathrm{n}=35)$ & $22-48(37 \pm 6, n=35)$ & $50.2-84.3(65.4 \pm 8.1, \mathrm{n}=65)$ & $42.6-69.1(56.4 \pm 5, \mathrm{n}=65)$ \\
\hline $407-674.1(530.6 \pm 68.1, \mathrm{n}=22)$ & $10-20(15 \pm 2, \mathrm{n}=57)$ & $7-19(15 \pm 2, \mathrm{n}=57)$ & $17-39(30 \pm 4, n=57)$ & $46.9-99.6(65.7 \pm 10.5, \mathrm{n}=105)$ & $40.2-83.9(56.2 \pm 10.3, \mathrm{n}=105)$ \\
\hline $397.4-466$ & $15-19(17 \pm 2, \mathrm{n}=5)$ & $18-20(19 \pm 1, \mathrm{n}=5)$ & $33-39(36 \pm 3, \mathrm{n}=5)$ & $50.5-63.3(56.5 \pm 4.1, \mathrm{n}=10)$ & $40.8-59.1(49.2 \pm 4.6, \mathrm{n}=10)$ \\
\hline $429-530(482 \pm 36, n=13)$ & $10-20(14 \pm 2, \mathrm{n}=27)$ & $11-22(14 \pm 2, \mathrm{n}=27)$ & $23-38(28 \pm 4, n=27)$ & $50-93(71 \pm 9, \mathrm{n}=45)$ & $38-74(57 \pm 9, \mathrm{n}=45)$ \\
\hline $245.4-501.1$ & 27 & 28 & 55 & $41.4-101.2(67.6 \pm 20.1, \mathrm{n}=10)$ & $26.6-43.9(36.3 \pm 5.8, \mathrm{n}=10)$ \\
\hline- & $17-26(22 \pm 3, n=6)$ & $13-27(20 \pm 5, \mathrm{n}=6)$ & $30-49(42 \pm 7, \mathrm{n}=6)$ & - & - \\
\hline
\end{tabular}

APPENDIX II. Extended.

\section{Ovary}

\begin{tabular}{|c|c|c|}
\hline Poral ovarian lobe & Aporal ovarian lobe & Ovarian isthmus \\
\hline $\begin{array}{l}65-578.4(378.6 \pm 89.7, \mathrm{n}=42) \\
66.5-155.8(121.7 \pm 25.2, \mathrm{n}=11) \\
300-366.9 \\
169.1-449.2(315.9 \pm 102.3, \mathrm{n}=9) \\
350.4 \\
159.4-430(334.2 \pm 77.1, \mathrm{n}=29) \\
533.2-564.1 \\
255-465.7(337.6 \pm 65.3, \mathrm{n}=25) \\
157.2-466(379 \pm 71.4, \mathrm{n}=24) \\
238.4-430(359 \pm 84.3, \mathrm{n}=4) \\
234-442(344 \pm 52, \mathrm{n}=14) \\
158-249.6(210.6 \pm 47.3, \mathrm{n}=3) \\
-\end{array}$ & $\begin{array}{l}175-972(725.3 \pm 148.5, \mathrm{n}=42) \\
18.2-29.5(22.5 \pm 3.5, \mathrm{n}=20) \\
620-674.1 \\
336.8-787.8(616.1 \pm 155.5, \mathrm{n}=9) \\
575.7 \\
491.8-910.9(684.3 \pm 114.8, \mathrm{n}=29) \\
872.3-966.8 \\
539.1-904.1(703.9 \pm 102, \mathrm{n}=25) \\
231.2-974.6(701.4 \pm 142.6, \mathrm{n}=24) \\
605.8-820(704.5 \pm 98.4, \mathrm{n}=4) \\
506-901(727 \pm 103, \mathrm{n}=14) \\
346.3-544.9(473.3 \pm 110.3, \mathrm{n}=3) \\
-\end{array}$ & $\begin{array}{l}75-280.8(184 \pm 36.7, \mathrm{n}=42) \\
10.7-18(14.1 \pm 2.1, \mathrm{n}=20) \\
197.2-200 \\
89.6-174.8(138 \pm 29.5, \mathrm{n}=9) \\
188.3 \\
99.5-200(150.7 \pm 27.1, \mathrm{n}=29) \\
136.5-211.8 \\
81.7-252.5(165.5 \pm 37.3, \mathrm{n}=25) \\
42.5-188.3(128.7 \pm 33.4, \mathrm{n}=24) \\
103.1-150(127.5 \pm 19.2, \mathrm{n}=4) \\
85-189(143 \pm 28, \mathrm{n}=14) \\
183.3-227.7(205.9 \pm 22.2, \mathrm{n}=3) \\
-\end{array}$ \\
\hline
\end{tabular}


APPENDIX III. Measurements obtained for Rhinebothroides moralarai according to host and geographic distribution.

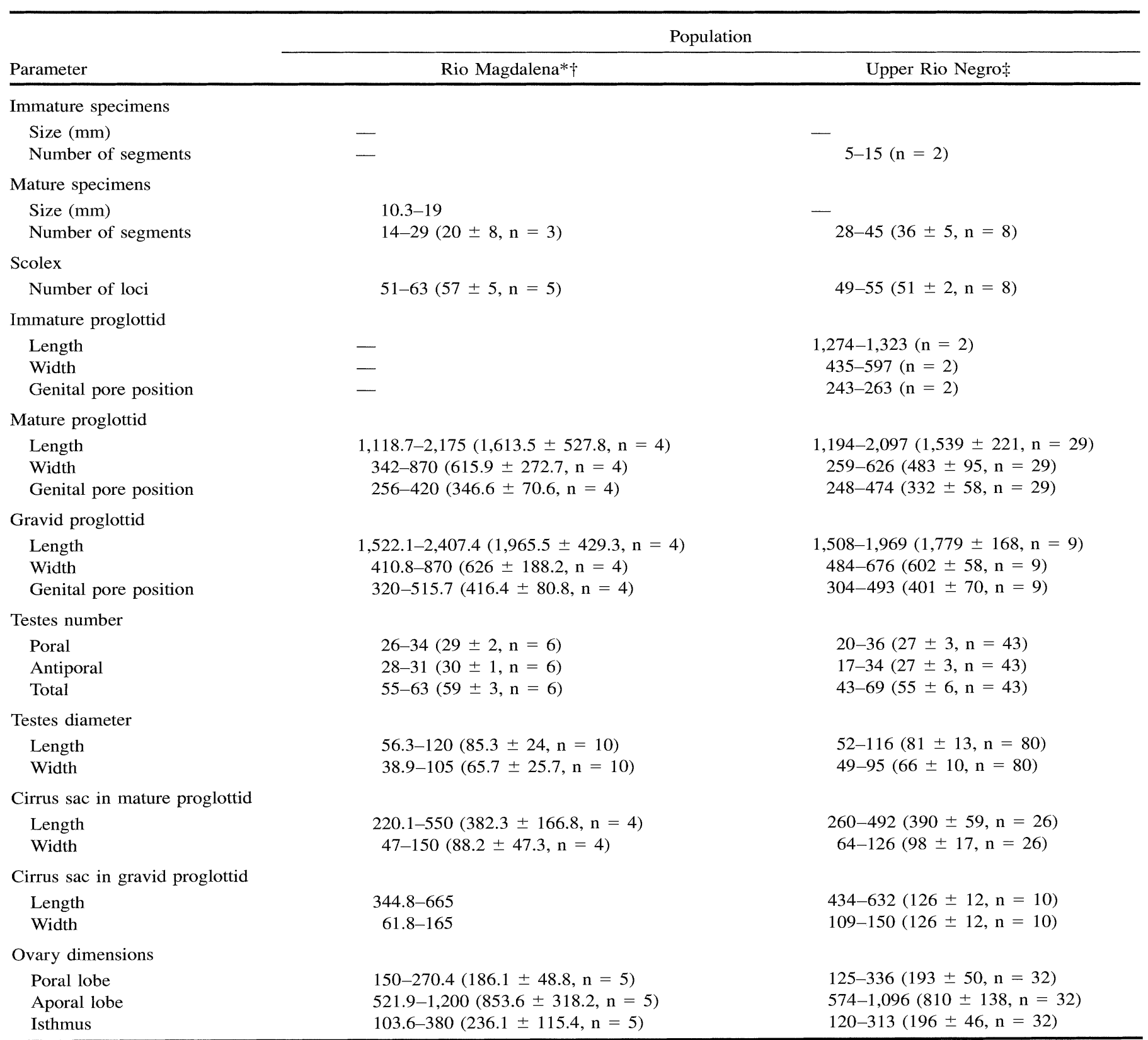

* Potamotrygon magnalenae.

$\uparrow$ Specimens collected by Brooks and Thorson (1976).

$\$$ Potamotrygon sp. (upper Rio Negro). 


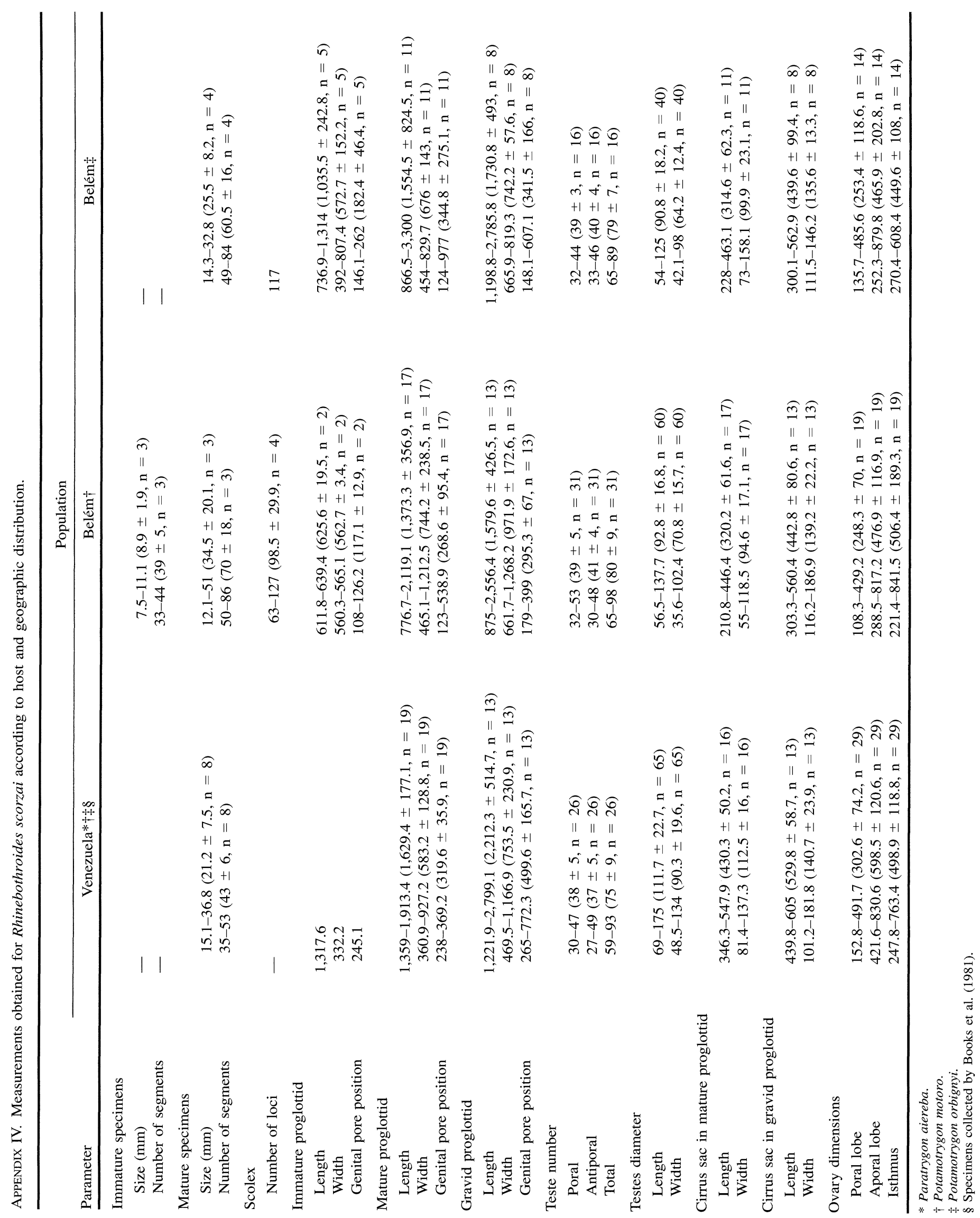

